\title{
Eleições no Brasil antes da democracia: o Código Eleitoral de 1932 e os pleitos de 1933 e 1934
}

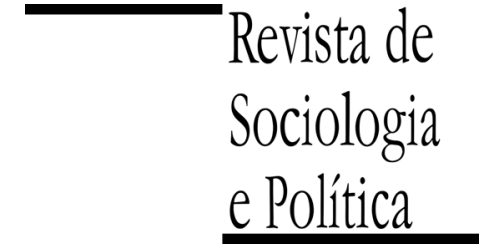

DOI 10.1590/1678-987315235604

\section{Thiago Silva e Estevão Silva}

\begin{abstract}
Resumo
Neste trabalho temos como objetivo compreender o processo de reconfiguração do quadro partidário e eleitoral brasileiro pós-1930 e anterior ao primeiro período democrático do país (1945-1964). Nossa análise centra-se em dois momentos: (i) a relação entre elites políticas e a construção de uma nova ordem política-institucional no país e (ii) os efeitos de mudanças institucionais sobre a competição e representação políticas. Demonstramos que as eleições realizadas em 1933 e 1934 são as primeiras eleições competitivas no Brasil em que às oposições vitoriosas é garantida a possibilidade de assumirem o poder. Esses pleitos expõem, portanto, um cenário muito diferente daquele frequentemente apresentado pela literatura consolidada sobre a Primeira República brasileira.
\end{abstract}

PALAVRAS-CHAVE: Primeira República; formação de partidos políticos; eleições; sistemas eleitorais, representação política.

Recebido em 17 de Setembro de 2014. Aceito em 28 de Abril de 2015.

\section{Introdução ${ }^{1}$}

${ }^{1}$ Os autores agradecem aos pareceristas anônimos da Revista de Sociologia e Política.
$\mathrm{E}^{\mathrm{s}}$ m geral, as análises sobre o primeiro período democrático brasileiro, inaugurado com a eleição de 1945, estão mais preocupadas em oferecer explicações para o seu ulterior colapso, com o Golpe Militar em 1964, a entender como funcionavam as eleições anteriores a esse período. Existe, assim, uma lacuna nos estudos eleitorais brasileiros que corresponde ao período anterior ao regime político de 1945 .

Neste trabalho buscamos preencher parte dessa lacuna ao considerarmos as eleições anteriores ao fechamento do sistema político brasileiro em 1937, isto é, propomos, à luz de dados originais, analisar as eleições realizadas no período pós-1930, mais precisamente os pleitos de 1933 e de 1934. A importância dessas eleições se reflete nos seguintes fatos: $(i)$ são essas as primeiras eleições com algum grau de competitividade eleitoral no Brasil, em que oposições passam a assumir o poder; (ii) elas expõem um cenário muito diferente daquele frequentemente apresentado pela literatura consolidada sobre a Primeira República brasileira e (iii) são realizadas em um contexto de reconfiguração partidária e posterior a escolhas institucionais cruciais para o sistema eleitoral brasileiro, oriundas do Código Eleitoral de 1932.

É sabido, por autores como Franco (1974), Leal (1975), Cardoso (1977) e Telarolli (1982), que a Primeira República foi marcada por constantes fraudes eleitorais, pela prática do "coronelismo," pela inexistência de oposição e pela inexistência de partidos nacionais, desenhando um sistema político caracterizado pela ausência de competição política e pelo fenômeno político que Leal (1975) denominou por governismo. Por conta das restrições à garantia do voto, por não ocorrer alternância no poder e pela consolidação de fenômenos como o do coronelismo (e todos os seus vícios correlatos), a Primeira República é assinalada na literatura corrente como um período de degeneração política do 
Brasil (Viana 1949; Souza 1974; Leal 1975; Kinzo 1980; Lamounier 2005). É bastante comum encontrar, nos escritos sobre essa época, referências à farsa e à impraticabilidade do sistema representativo brasileiro.

No entanto, encontramos um cenário bastante diferente quando olhamos para o quadro partidário e para as eleições disputadas três anos depois da Revolução de 1930, mais especificamente os pleitos para a Constituinte de 1933, para a Câmara Federal e para as Constituintes Estaduais em 1934. Encontramos nesses pleitos um cenário em que o jogo político-partidário permanece, de certo, ainda regional, porém, o quadro partidário se apresenta bem mais difuso e com algum grau de competitividade. Portanto, a situação corrente no primeiro período republicano-de um partido único por estado e marcado pelo governismo-dava sinais claros de desestruturação e se iniciava uma situação de razoável competição política em que às oposições vitoriosas era garantida a possibilidade de assumirem o poder.

Assim, é de substancial importância compreender esse processo de reconfiguração do quadro partidário brasileiro e, principalmente, identificar os elementos que influenciaram o desencadear dessas mudanças. Historiadores e juristas como Franco (1974), e também cientistas políticos como Sadek (1995) e Hollanda (2009), chamam a atenção para as reformas eleitorais e institucionais presentes no Código Eleitoral de 1932, como a adoção do Voto Secreto, a criação da Justiça Eleitoral e a Representação Proporcional, às quais vieram a contribuir para o enfraquecimento da lógica partidária da Primeira República e para a estruturação de um novo contexto partidário.

O Código Eleitoral, criado em 1932 e baseado em reformas eleitorais prévias, é considerado um momento de grande evolução das instituições políticas brasileiras. Com a adoção do Código de 1932, a circunscrição eleitoral para as eleições de governadores e deputados passaria a ser delineada de acordo com a extensão territorial dos estados brasileiros, e os eleitores poderiam votar em tantos nomes de candidatos quanto fossem as cadeiras do estado na Câmara dos Deputados (Nicolau 2002, p.51). Essas duas regras, que se assemelham às modificações presentes na lei eleitoral de 1890 , representaram mudanças importantes no processo eleitoral do país quando comparado com o processo vigente entre 1892 e 1930. Porém, ainda mais relevantes foram as alterações quanto ao sistema eleitoral e à responsabilização pela apuração dos resultados eleitorais. Pela primeira vez no país fora adotado o sistema eleitoral proporcional (misto), e a apuração passaria a ser de responsabilidade da recém-criada Justiça Eleitoral ${ }^{2}$. Assim, com a aprovação deste Código, o poder de controlar as eleições não mais figuraria nas mãos do governo. Desse momento em diante todos os trabalhos eleitorais - o alistamento, a apuração dos votos e o reconhecimento e validação dos eleitos - estariam sob a responsabilidade da Justiça Eleitoral. Se por um lado a Justiça Eleitoral não aboliu completamente as fraudes, muito devido à dependência dos membros da magistratura ao governismo e pela conivência dos juízes às manipulações utilizadas, foram nos pleitos de 1933 e 1934, sob regulação do Código de 1932, que "situações estaduais chegaram a ser derrotadas e uma numerosa bancada de oposição, avolumada mais tarde pela disputa da sucessão presidencial, teve assento na Câmara Federal" (Leal 1975, p.234).

Com isso, um dos elementos considerados neste trabalho é o efeito que as reformas eleitorais contidas no código de 1932 podem ter tido sobre a competição política e na configuração do sistema partidário brasileiro. Dito de outra forma, a mudança do sistema eleitoral e a criação de novas instituições impactaram o quadro partidário brasileiro, provocando substanciais mudanças em sua lógica? Para responder a essa pergunta nossa análise se concentra em dois 
3 Tenentes e parte das oligarquias dissidentes - como alguns atores do Rio Grande do Sul, de Minas Gerais, o Partido Democrático de São Paulo e as oligarquias do Norte e Nordeste. momentos: (i) na relação entre elites políticas e a construção de uma nova ordem política-institucional no país e (ii) nos efeitos de mudanças institucionais sobre a competição política.

Um argumento bastante difundido na literatura (Santos 1937; Franco 1965; Sadek 1995; Hollanda 2009) afirma que os atores políticos tinham a intenção, com as reformas eleitorais, de moralizar o processo eleitoral brasileiro. No argumento desses atores eram as regras eleitorais vigentes na Primeira República que permitiam a prática da fraude, do "coronelismo" e do sufocamento das oposições, resultando em um sistema representativo ilegítimo. Assim, o Código Eleitoral de 1932 seria a condição sine qua non à concretização dos objetivos propalados pelos reformadores, pois, com a introdução do voto secreto, da justiça eleitoral e da representação proporcional, a prática da fraude, a violência sobre o eleitor e a hegemonia política dos partidos republicanos estariam comprometidas.

Esse argumento tradicional será relativizado neste trabalho. Não é o caso aqui de negar a importância e o avanço das instituições políticas do país permitido pelo Código de 1932, nem mesmo de negar a existência de práticas para fraudar as eleições e fabricar seus resultados. Mas exploraremos uma hipótese complementar em que as estratégias abertas aos atores no processo de reforma das instituições eleitorais neste período serão traçadas. Para Vargas e o grupo político ${ }^{3}$ que o acompanhou na Revolução de 1930, o grande inimigo político eram as oligarquias, uma vez que elas mantinham o monopólio político pela práticas eleitorais fraudulentas, e o excessivo federalismo que culminou na política dos governadores e no domínio político de um partido por estado (os partidos republicanos). Infere-se, de acordo com a nossa hipótese complementar, que um dos objetivos dos revolucionários era minar os recursos e vantagens políticos das oligarquias, não apenas com o intuito de aperfeiçoar as instituições republicanas, mas visando, como esperamos deixar claro, ganhos de influência sobre o sistema político e eleitoral.

Portanto, este trabalho não se limitará a apresentar uma explicação de viés institucional para o quadro partidário mais plural em 1933 e 1934. A linha de raciocínio também se beneficiará de elementos contingenciais, principalmente o jogo político travado pelas forças políticas relevantes do período, procurando compreender a lógica desenvolvida no momento pós-Revolução de 1930, e trazer à luz as preferências dessas forças políticas, seus projetos de construção político-institucionais e suas articulações visando o ganho de capital político para a consecução de seus objetivos. Nesse sentido, a aglutinação de apoio político ao Governo Provisório era essencial para o objetivo de enfraquecer politicamente as antigas oligarquias, ou seja, nesse argumento, o formato do novo quadro partidário foi a melhor escolha possível naquele contexto. Em outras palavras, entre as escolhas abertas aos atores políticos do regime recéminstituído, a opção maximizadora dos objetivos do governo provisório era a abertura de uma competição política controlada regionalmente.

$\mathrm{O}$ artigo estrutura-se da seguinte forma. Na seção II, apresentaremos os modelos analíticos sobre a reforma eleitoral, os argumentos sobre as inovações institucionais presentes no Código Eleitoral de 1932 e os esperados impactos dessas novas instituições na lógica partidária. Na seção III, delineamos o processo de formulação do Código Eleitoral de 1932 à luz da hipótese complementar apresentada neste trabalho. Na seção IV, reconstruiremos a dinâmica política desenvolvida após a Revolução de 1930 e analisaremos os impactos eleitorais das escolhas institucionais tomadas pelos líderes do Governo Provisório e pela subcomissão responsável pelo Código de 1932. Nessa seção também serão apresentados novos dados que comprovam as mudanças no 
quadro partidário e eleitoral pós-Revolução. Na seção $\mathrm{V}$, apresentamos nossas considerações finais.

\section{Modelos Analíticos sobre a Reforma Eleitoral de 1932}

${ }^{4} \mathrm{O}$ autor se refere a partidos, grupos políticos e à figura individual de um político como termos intercambiáveis.
Nesta seção serão mapeados os modelos analíticos e os mecanismos explicativos relacionados à reforma eleitoral de 1932, com foco na ação estratégica dos atores políticos. Ou seja, os modelos aqui expostos apresentam uma explicação aos processos de reforma eleitoral calcada na ação estratégica dos atores políticos inseridos no processo de construção de uma nova ordem políticainstitucional para o país.

Benoit (2004) considera que os estudos sobre a escolha de sistemas eleitorais são estudos de caso construídos indutivamente. Ele atribui tal fato às dificuldades de generalizações desse problema, que apresentam uma lógica muito peculiar e inusitada. No entanto, a literatura sobre o assunto tem avançado em apresentar novas explicações. Benoit (2007) e Renwick (2010), por exemplo, baseados nos estudos de casos existentes, elaboraram tipologias explicativas, com a finalidade de encontrar generalizações quanto ao processo de escolha de diferentes sistemas eleitorais.

Renwick (idem), primeiramente, olha para os atores políticos responsáveis pelas reformas eleitorais e classifica os processos em dois tipos: o primeiro é denominado pelo autor como "Elite Majoritary Imposition" e corresponde àqueles processos em que os políticos ${ }^{4}$ controlam toda a dinâmica da reforma, ou seja, os únicos atores com capacidade decisória são os próprios políticos. Já o segundo tipo é denominado pelo autor como "Elite Mass Interaction" e se refere aos processos em que os políticos perdem sua hegemonia decisória para outros atores, como a sociedade civil, poder Judiciário, especialistas e atores externos.

Não obstante, tanto Renwick (idem) como Benoit (2001; 2004; 2007) salientam que as explicações sobre reforma eleitoral devem se apegar à identificação das motivações dos atores na escolha do sistema. Nos termos colocados por Renwick (2010, pp.36-37):

"Os atores podem desejar mudar o formato de todo sistema partidário. Atores podem desejar esta mudança por dois motivos. Um é que eles acreditam que um formato diferente seria melhor para o país - maior representação [...]. A outra razão é que certos atores acreditam que seu próprio poder será reforçado se o sistema partidário for reconfigurado".

Assim, os modelos analíticos sugeridos pelo autor apresentam dois elementos estratégicos para a ação dos atores políticos: (i) escolhas institucionais em que os atores se guiam por valores, isto é, em que os atores políticos buscam atender interesses públicos, como uma maior representatividade da sociedade; (ii) escolhas institucionais em que a motivação dos atores é a busca pela maximização de poder, isto é, buscam atender seus próprios interesses.

Essas duas categorias de ações estratégicas dos atores políticos no processo de formulação do Código de 1932 serão desenvolvidas abaixo. Cabe aqui salientar, que elas não devem ser vistas como mutuamente exclusivas. Isto é, a estratégia de "maximização do poder" pode coexistir com uma estratégia "guiada por valores", tais como a modernização do país, particularmente ligada ao desenvolvimento industrial e à formação de uma burocracia pública.

\section{II.1. O Código de 1932: A hipótese tradicional do aperfeiçoamento da democracia}

De acordo com a literatura especializada sobre o primeiro período republicano (Santos 1937; Franco 1965; Leal 1975; Sadek 1995; Hollanda 2009), a 
intenção dos atores políticos na reforma eleitoral de 1932 relaciona-se à tentativa de aprimorar o então vigente regime representativo no país - a busca por uma representação mais genuína da sociedade e pela construção de efetivos partidos políticos.

A maioria das interpretações sobre a Primeira República aponta o elemento regional como condição sine qua non para se entender a lógica política da época. Isto é, a força motriz da dinâmica política neste período seriam os estados somados aos interesses de suas elites. A literatura destaca que os atores políticos eram regionais e que a mentalidade republicana era essencialmente antipartidária quanto à construção de partidos nacionais; o que existia eram partidos estaduais que representavam as oligarquias dos estados. Como pode ser observado neste trecho do trabalho de Franco (1975, p.63):

\footnotetext{
“A primeira República foi, no Brasil, essencialmente anti-partidária, no sentido nacional. Todas as tentativas de formação de partidos nacionais fracassaram ou eram simples coalizões dos partidos estaduais, sendo estes a verdadeira realidade política, oficialmente reconhecida como dogma pelo presidente Campos Sales [...]. Os famosos PR [Partidos Republicanos] estaduais representavam as oligarquias dos estados, às vezes o domínio aberto de uma só família, principalmente nos estados do Norte".
}

Franco (idem) argumenta que a ausência de partidos nacionais como canais de representação e instrumentos de governo catalisou a criação de um arranjo institucional que atribuiu a este uma inovadora lógica de funcionamento, conhecida como a política dos governadores. A lógica dessa política consistia em uma correia de trocas entre as forças municipais, estaduais e federal; os primeiros, representados pela figura do chefe político local, os segundos, pelos governadores de estado e o terceiro, pelo presidente da república.

O ator municipal tinha o compromisso de obter os votos necessários ao candidato apoiado pelos governadores e presidente e, assim, ele obtinha autonomia política municipal e os recursos provenientes do Estado. $\mathrm{O}$ ator estadual se comprometia com o chefe político municipal a satisfazer seus interesses e necessidades em troca dos votos, e com o presidente a apoiar os seus candidatos em troca da autonomia política estadual. $\mathrm{O}$ ator federal, por sua vez, necessitava do apoio dos estados para conseguir maioria legislativa e, para isso, concedia autonomia política aos governadores.

Para Cardoso (1977), esse pacto objetivava atingir, basicamente, três metas. A primeira era a independência entre os poderes com a preeminência do presidente. A segunda, decorrente da primeira, alicerça-se na ideia de que o Legislativo não governa, isso é, "o poder, que pela natureza de suas prerrogativas, se acha em condição de esclarecer e dirigir, é o executivo" (idem, p.49). E a terceira era a formação de maiorias parlamentares harmoniosas com o Executivo.

Assim, de acordo com Leal (1949, p.43), as eleições em níveis municipal e estadual, na ausência de partidos nacionais, conduziam a um mercado entre o Estado - fornecedor dos serviços públicos - e os coronéis que disponibilizavam os "votos de cabresto". Além desse fenômeno, que Leal tornou famoso pela nomenclatura de coronelismo, a literatura especializada sobre o período é pródiga em destacar a constante prática de fraudes eleitorais.

Assim, esse cenário apresentado pela literatura a respeito da Primeira República - marcada pelo coronelismo, pelas fraudes eleitorais e, portanto, pelo falseamento da representação - resultaria em um sistema político com duas características marcantes: o elevado situacionismo (ou governismo) e a ausência de competição política. Eis a razão da Primeira República ser assinalada 
${ }^{5}$ Os autores dividem o processo eleitoral em quatro etapas: (i) alistamento, definição dos distritos, locais de votação e indicação dos membros que comporiam as mesas eleitorais; (ii) momento eleitoral (a votação em si); (iii) momento da apuração pelas juntas apuradoras e elaboração das atas; (iv) reconhecimentos dos diplomas dos eleitos (Ricci \& Zulini 2014, pp.447-448).
${ }^{6}$ Ainda assim, as reflexões dos dois autores não são idênticas. Cabral (1929) tece críticas à proposta de Assis Brasil, argumentando que o sistema proporcional proposto por este, ao incorporar critérios majoritários, pecava por não ser um sistema proporcional puro. Cabral também critica o critério de como um período de degeneração política do Brasil (Viana 1949; Leal 1975; Souza 1974, p.203; Kinzo 1980; Lamounier 2005, p.38).

A ausência de competição política e o peso das fraudes eleitorais no processo político da Primeira República são relativizados em estudos recentes (Ricci \& Zulini 2012; 2014). Para esses autores, existia competição eleitoral no período analisado. Isto é, grupos políticos de oposição e grupos governistas se enfrentavam nas disputas eleitorais municipais. No entanto, o que não se confirmava necessariamente era o acesso dos grupos oposicionistas à representação parlamentar. E isso não pelo uso constante das fraudes como afirmado pela literatura tradicional, mas sim pelo domínio da burocracia eleitoral controlada pela situação. Em outras palavras, os gupos políticos situacionistas controlavam todas as etapas do processo eleitoral ${ }^{5} \mathrm{e}$, dessa forma, influenciavam os resultados eleitorais. O mecanismo da fraude era apenas utilizado quando o grupo político situacionista não conseguia controlar as etapas do processo eleitoral, tendo que se utilizar do recurso da fraude para manter sua hegemonia política (Ricci \& Zulini 2014). Nesse sentido, a competição política definida como a possibilidade da oposição vencer as eleições - definição utilizada neste trabalho - não estava de todo ausente no primeiro período republicano do país. No entanto, não estava garantida a oposições vitoriosas a possibilidade destas virem a assumir o poder, o que ocorreria, como veremos, nos pleitos de 1933 e 1934.

Os argumentos sobre o processo de formulação da reforma eleitoral de 1932 propostos neste trabalho levam em consideração o contexto descrito acima. Primeiramente, é de substancial importância analisar as reflexões produzidas por dois membros que participaram da subcomissão responsável pela criação do Código Eleitoral de 1932 - Assis Brasil e João da Rocha Cabral. Nota-se primeiramente que, de fato, não estava ausente dessas reflexões críticas ao status quo o desejo de mudanças em relação ao sistema representativo anterior à Revolução de 1930. Para Assis Brasil e Cabral, era preciso reformular o sistema representativo brasileiro com a finalidade de implantar uma "verdadeira representação" no país e superar os vícios presentes na Primeira República.

De acordo com Assis Brasil, em sua obra Democracia Representativa - do voto e do modo de votar, de 1931, a adoção do sistema proporcional misto é justificada pela confiança de que o princípio da proporcionalidade iria permitir aos grupos minoritários mais organizados acesso real ao congresso, os quais deveriam ter esse direito garantido, uma vez que o pluralismo de ideias se constitui em um dos pilares da democracia representativa moderna. Segundo Assis Brasil, o processo eleitoral deveria garantir "o surgimento sem utilização da fraude ou violência de um grupo forte, sólido e capaz de governar e assegurar, ao mesmo tempo, que os grupos minoritários mais organizados também tenham suas vozes ouvidas" (Assis Brasil 1983, p.145).

João C. da Rocha Cabral, relator do projeto do Código Eleitoral de 1932, em sua obra de 1929, Sistemas Eleitorais do ponto de vista da representação proporcional das minorias, também defende uma reforma eleitoral no país como a única maneira de curar a "anemia política" gerada pelos processos eleitorais viciados. Assim, Cabral (1929) defende o sistema eleitoral proposto por Assis Brasil ${ }^{6}$, argumentando que o princípio da proporcionalidade do sistema iria aumentar o escopo representativo da sociedade, possibilitando, às minorias, chances de serem representadas, além de o sistema de listas partidárias incentivarem a partidarização, em contraste ao modelo partidário da Primeira República.

Assim, a interpretação de parte da literatura sobre a reforma eleitoral de 1932 considera que os atores políticos responsáveis pela reforma objetivavam corrigir os problemas no sistema representativo brasileiro, destacados pelos autores acima. 
quociente eleitoral, afirmando que esse fator favoreceria demais a maioria em detrimento das minorias e tornaria o quociente difícil de ser atingido pelas oposições.
Esse argumento encontra respaldo nas palavras de Santos (1937, p.455):

“Toda a vida republicana e mesmo na última fase da monarquia serviram de pressuposto ao Código de 1932. Indiscutivelmente, foram os vícios em evidência pela prática das antigas leis, e falsificação das eleições, o sentido antidemocrático das campanhas políticas, a angústia das minorias sufocadas, que contribuíram e prepararam através (de) demorados "processos" o sistema finalmente consagrado no Código de 1932 e ratificado na lei n 48 , de 4 de maio de 1935".

$\mathrm{O}$ argumento do aperfeiçoamento democrático aparece também em Afonso Arinos de Mello Franco (1965), quando este afirma que um dos objetivos da adoção da representação mista no novo código eleitoral seria o de incentivar a nacionalização dos partidos políticos, evitando o regionalismo presente no experimento político anterior.

Sadek (1995) dedica seu argumento ao estudo da Justiça Eleitoral e explicita que a criação desta foi fruto da motivação dos atores revolucionários em reduzir a violência das disputas eleitorais e de atingir a "verdade eleitoral" através do combate às fraudes, tão recorrentes na Primeira República. A autora argumenta que as eleições deveriam ser blindadas da influência dos atores políticos e que a criação de uma instituição neutra seria a estratégia mais viável naquele momento.

Hollanda (2009) também argumenta que, ao introduzir o princípio da proporcionalidade no processo eleitoral, Assis Brasil objetivava superar o problema da representação das minorias, buscando atribuir aos grupos políticos minoritários uma expressão política mais refinada e substancial, ou seja, a introdução de um mecanismo mais sofisticado de conversão de votos em cadeiras parlamentares.

Notamos, portanto, ao longo do debate travado na literatura sobre a política eleitoral da Primeira República e também sobre as motivações que levaram a uma profunda reforma das instituições eleitorais brasileiras em 1932, um ponto comum, qual seja, eram os vícios presentes no sistema representativo os grandes instrumentos institucionais que permitiam às oligarquias obter o monopólio político, excluindo, quase que completamente, a existência de oposições e prejudicando a introdução da prática democrática no país.

Assim, a interpretação desses autores para as reformas eleitorais de 1932 é que a elite política, com a Revolução de outubro de 1930, procura, via mudança das instituições eleitorais, corrigir os defeitos de nosso sistema representativo e abrir o caminho para o desenvolvimento da democracia no país.

\section{II.2 Uma hipótese complementar sobre a reforma de 1932}

${ }^{7}$ Nos referimos aqui a Democracia Representativa do voto e do modo de votar, de João Francisco de Assis Brasil (1983) e a Sistemas Eleitorais
Esta seção se dedicará a apresentar um argumento complementar à explicação apresentada acima, em que o elemento original reside em traçar as estratégias dos atores políticos ao reformarem as instituições eleitorais, procurando colocar em evidência a relação entre elites políticas e suas escolhas na construção da nova ordem política-institucional do país.

A explicação consolidada preocupa-se com o papel das ideias e com os discursos propalados pelos defensores das reformas, e, a partir da observação destes, apresenta deduções das causas da reforma eleitoral. Ou seja, com base na interpretação das obras dos personagens envolvidos na reforma de $1932^{7}$ são extraídas as deduções sobre os objetivos e motivações que moveram os atores a optarem pela mudança da legislação eleitoral. A contribuição principal aqui apresentada diz respeito ao fato de a explicação tradicional por vezes negligenciar o jogo político e os interesses envolvidos no período entre 1922 e 1935. 
do ponto de vista da representação proporcional das minorias, de João C. da Rocha Cabral (1929).

${ }^{8}$ Já que essas eram os principais inimigos políticos do grupo revolucionário de 1930
Nesse sentido, o argumento complementar aqui proposto corresponde, no arcabouço analítico de Renwick (2010), ao tipo Elite Majoritary Imposition. Como já trabalhado no argumento da hipótese clássica, notamos uma interpretação geral de que a Primeira República foi marcada pelo monopólio político dos partidos regionais (republicanos), especialmente os dos estados de Minas Gerais e São Paulo (ver também Lessa 1999). Em nosso argumento, Getúlio e o grupo político que o apoiou visavam, com a reforma política posterior a 1930, não apenas a modernização do sistema político brasileiro, mas também a maximização de seus poderes e uma maior influência sobre o sistema político. Para que esse objetivo se concretizasse seria necessário enfraquecer politicamente as oligarquias ${ }^{8}$ através da eliminação dos recursos que as sustentavam no poder. Entre esses recursos se destacava o monopólio político dos partidos republicanos, conseguido graças às fraudes eleitorais, ao controle da burocracia eleitoral e ao sufocamento das minorias políticas.

Portanto, nesse argumento, Getúlio e seu grupo político de apoio, objetivando ganhar espaço no sistema político pós-revolução, decide enfraquecer politicamente as oligarquias através da substituição das instituições eleitorais, que garantiam aos partidos republicanos vitórias unânimes. E a implantação do Código Eleitoral de 1932 é um elemento-chave para alcançar esse objetivo, pois suas inovações institucionais possibilitariam chances reais de representação a grupos minoritários e, como consequência, o aumento no número de forças políticas. Isso poderia levar a uma reconfiguração do sistema partidário, que, por sua vez, favoreceria a construção de uma base política de apoio ao Governo Provisório.

Assim, as reformas eleitorais, presentes no Código Eleitoral de 1932, não podem ser interpretadas somente pela motivação dos atores políticos em fortalecer um regime democrático através da moralização do processo eleitoral, porque, apesar desse propalado objetivo, estava presente também o projeto do governo provisório de enfraquecimento político das oligarquias por meio da eliminação dos recursos que as sustentavam no poder, como o excessivo regionalismo, a falsa representação e o monopólio político dos partidos republicanos, como destacam Gomes (1974), Octávio (1984) e Souza (1990).

Uma leitura mais atenta dos fatos e a apresentação de novos dados corroboram nossa hipótese complementar. Iniciaremos pelos fatos que revelam os próprios antecedentes políticos dos três integrantes responsáveis pela realização da reforma eleitoral, começando pelo líder da Subcomissão da lei e processos eleitorais, Assis Brasil.

\section{O Processo de Formulação do Novo Código Eleitoral (1922-1935)}

A literatura discutida acima chama atenção sobre a possível correção das falhas do sistema representativo brasileiro com a reforma de 1932 proposta por Assis Brasil. No entanto, como aponta Antonacci (1981), Assis Brasil fazia parte da classe dominante gaúcha, marginalizada do poder naquele momento. Nos termos de Antonacci (idem, p.107) "Assis Brasil, dissidente do PRR [Partido Republicano Rio Grandense] num sistema de poder que não dava espaço para a atuação das oposições, preocupou-se em debater os fundamentos da situação política vigente".

Antonacci (idem) destaca que, ao longo da Primeira República, Assis Brasil sempre esteve do lado da oposição em seu estado. Logo no início da República, ele se torna dissidente do PRR e se filia ao Partido Federalista, que fazia oposição. Depois, Assis Brasil se tornou integrante do Partido Democrático (PD) e, por fim, se tornou líder do Partido Libertador, sendo ferrenho opositor do PRR e do presidente do estado (Borges de Medeiros). Assis Brasil sempre 
${ }^{9}$ Composta por integrantes do Partido Libertador e de dissidentes do PRR.

${ }^{10}$ Partido opositor ao Partido Republicano Paulista (PRP).

${ }^{11}$ Após esse fato, Assis Brasil participa da Aliança Liberal e da Revolução de 1930. contestou o monopólio político do PRR defendendo o rodízio no poder e a representação das minorias, até que, em 1923, após se candidatar ao governo do estado por uma coligação oposicionista, e sair derrotado dela, rebelou-se e organizou a Revolução de 1923, que, a princípio, não conseguiu seu objetivo - a quebra do monopólio político borgista e de seu partido - mas que preparou o terreno para a vitória de Getúlio Vargas, em 1928, para presidente do estado.

Trindade (1979) também argumenta que Assis Brasil, além de ter sido da oposição ao governo estadual, também apresentava a mesma postura política no plano nacional, tendo apoiado todas as candidaturas civis de oposição à Presidência da República. Esse comportamento ganha maior relevância após a revolução de 1923, com o apoio de Assis à criação da Aliança Libertadora no Rio Grande do Sul (coligação das forças oposicionistas do estado) ${ }^{9}$ e sua liderança na aliança desta com o Partido Democrático de São Paulo ${ }^{10}$ e com o Partido Democrático Socialista (PDS) do Rio de Janeiro. Em 1926, Assis funda um partido de oposição nacional, o Partido Democrático Nacional (PDN), com propostas políticas alternativas às das oligarquias dominantes ${ }^{11}$.

Em relação a João da Rocha Cabral, Pires (2009) argumenta que ele não apresenta uma trajetória política tão rica como a de Assis Brasil, sendo uma figura mais restrita à política piauiense, tendo como único cargo político a cadeira de deputado federal, no ano de 1920. No entanto, quatro anos depois, por ser do partido de oposição em seu estado, passa a sofrer com a lógica política reinante na Primeira República.

Isso se evidencia nas palavras do próprio Cabral (1929, p.11):

\begin{abstract}
"Quando, em 1924, pela última vez nos dirigimos ao eleitorado piauiense rogando-lhe a honra dos seus sufrágios, para uma reeleição, que o despotismo então reinante no estado 'consentira' até às vésperas dos trabalhos eleitorais, e logo sorrateiramente 'proibiu' com imprudência descomunal, mandando substituir nosso nome nas votações, pelo de um adolescente e desconhecido testa de ferro, que deveria guardar, como de fato guardou, a cadeira na câmara, para o governador saliente $[\ldots]$ "..
\end{abstract}

A partir desse episódio político, Pires (2009) aponta que Cabral começa a escrever artigos em jornais da época comparando as regras eleitorais de outros países com as do sistema eleitoral brasileiro, procurando argumentar sobre a falência de nosso sistema representativo. Esses artigos deram substância a Cabral para que, no ano de 1929, ele publicasse o livro anteriormente citado, Sistemas eleitorais do ponto de vista da representação proporcional.

O terceiro integrante da Subcomissão de elaboração do Código de 1932, que acabou não participando da redação final por motivos de saúde, o paulista Mário Pinto Serva, era também ligado a forças políticas oposicionistas na Primeira República. De acordo com Pires (2009), foi um dos fundadores do PD de São Paulo e, mais tarde, juntamente com Assis Brasil, liderou o processo de fusão entre a Aliança Libertadora e o PD, para que, em 1927 fosse fundado o PDN. De acordo com Porto (2002), Serva também apresentava estudos ligados ao sistema eleitoral, sendo que, em 1931, durante os trabalhos da subcomissão, ele publica a Reforma Eleitoral, mencionando vários pontos que já haviam sido propostos pelos demais integrantes da subcomissão acima citados e que estariam presentes no Código de 1932, entre eles: o voto secreto, o sufrágio universal e a representação proporcional.

Portanto, como se observa, os responsáveis pela reforma da legislação eleitoral apresentam antecedentes políticos condizentes com os objetivos do Governo Provisório. Eram todos eles antigos opositores dos partidos republicanos e dos instrumentos que sustentavam estes no poder. Assim, esses personagens eram figuras políticas interessadas nas reformas; eram, ao mesmo 
tempo, especialistas em sistemas eleitorais e, politicamente, oposicionistas engajados.

Em vista disso, podemos destacar que as propostas de representação política feitas por Assis Brasil, Cabral e Serva, em suas obras sobre o assunto, não eram modelos interessados apenas em aperfeiçoar o sistema representativo brasileiro, mas, também, apresentavam uma motivação política, uma vez que queriam propor alterações no sistema eleitoral em um período em que seus interesses políticos estavam subjugados ao modelo de sistema eleitoral vigente. Opositores dos partidos republicanos na Primeira República e adeptos da Revolução de 1930, eles e o Governo Provisório tinham influência política a ganhar com a mudança do sistema eleitoral.

Assim, e de acordo com casos semelhantes destacados por Renwick (2010), esses reformadores atuaram como lideranças políticas que utilizaram seus conhecimentos a fim de criar uma visão interessada sobre o assunto e angariar apoio político para elas, procurando apresentar suas posições como a melhor opção para o funcionamento da democracia e deslegitimar a situação política que contestavam, argumentando que essa situação correspondia ao grande mal da política brasileira. Por isso, podemos destacar o fato de Vargas ter passado a eles a responsabilidade da reforma eleitoral. Não porque tivessem como único objetivo melhorar nosso sistema representativo e nossa democracia, mas, também, porque essas figuras eram atores políticos (incluindo Vargas, obviamente) com interesses na reforma e, consequentemente, no enfraquecimento político dos partidos republicanos.

Em suma, os atores envolvidos na elaboração do código eleitoral de 1932 tinham dois objetivos que se completam: primeiro, corrigir as mazelas presentes no nosso sistema representativo, e segundo - como os principais inimigos políticos dos revolucionários eram os que se beneficiavam, politicamente, dessas mazelas - substituir as instituições eleitorais da Primeira República. Esses passos eram fundamentais para o enfraquecimento das oligarquias e concretização dos objetivos do grupo que assumiu o poder com o advento da revolução de 1930 .

De fato, os atores revolucionários objetivaram, com a promulgação do Código de 1932, corrigir defeitos do sistema representativo brasileiro, mas isso incluía alterações na lógica partidária da Primeira República que seriam benéficas a seus interesses políticos. Primeiro, no caráter regionalista do quadro partidário da Primeira República e, segundo, na tentativa de incentivar um pluralismo partidário, visto que os partidos republicanos monopolizavam a cena política nesse período e não abriam espaço para a atuação das minorias.

Para Franco (1974), as alterações institucionais presentes no Código de 1932 tiveram profundos efeitos sobre o novo cenário eleitoral-partidário estabelecido nos pleitos subsequentes. Como aparece neste trecho em uma de suas obras:

"O Código não promoveu [...] a criação de organizações partidárias nacionais e por isso mesmo, as eleições para a constituinte de 1934 se processaram nos velhos moldes do partidarismo estadual. Houve, contudo, uma diferença, que foi a divisão interna dos Estados. Com efeito, as garantias acima consignadas permitiram às oposições estaduais, uma liberdade de ação desconhecida no velho presidencialismo de 'apoios incondicionais' e das unanimidades forjadas na ata falsa e no chanfalho da polícia” (idem, p.63).

Na próxima seção apresentamos novos dados com base em Boletins Eleitorais da década de 1930 (TSE do Brasil 1936), até aqui não explorados pela literatura, que corroboram nossa hipótese complementar e os efeitos decor- 
rentes das mudanças institucionais sobre as transformações partidárias e eleitorais do período em tela ${ }^{12}$.

\section{A Dinâmica Política Pós-Revolução de 1930}

\author{
${ }^{12}$ A origem dos dados, como \\ foram coletados e quais as \\ fontes primárias podem ser \\ consultados no Anexo $B$ - \\ Notas Metodológicas, onde \\ também se encontra a \\ classificação detalhada dos \\ atores políticos no que diz \\ respeito às suas respectivas \\ posições políticas (governo ou \\ oposição), bem como a quais \\ grupos pertenciam.
}

O período compreendido após a Revolução de 1930 até a pré-instalação da Constituinte de 1933 é, de acordo com a literatura, marcado por grande instabilidade. Gomes (1974) argumenta que o período de 1930-1932 é marcado pelos conflitos de interesse que começam a emergir entre os atores que compunham a aliança liberal, porque, de um lado, encontrava-se o grupo dos tenentes (tenentistas) com um projeto de centralização política, cuja base ideológica residia na negação das instituições liberais e, de outro, as oligarquias dissidentes, com o objetivo de reformar as instituições que existiam na época.

O contexto da Constituição elaborada pelo governo provisório favorece o fortalecimento do Tenentismo, que passa a influenciar, substancialmente, as decisões programáticas do governo. Esse fato provoca um incômodo nas oligarquias, já que os tenentes e Getúlio, objetivando efetuar uma centralização política, iniciam ações no sentido de eliminar os principais obstáculos à consecução dessa centralização: o regionalismo e os tradicionais partidos estaduais republicanos. Isso provoca uma cisão na base de apoio do governo provisório, colocando, assim, de um lado, as oligarquias do Centro-Sul e, de outro, os tenentistas e as oligarquias do Norte-Nordeste.

Eis o esboço do conflito político travado nesse momento: de um lado, parte das oligarquias que apoiaram Getúlio no processo revolucionário e as tradicionais oligarquias derrotadas na Revolução de 1930 - ambas favoráveis à constitucionalização do país, e de ideologia liberal - e, de outro lado, os tenentes contrários à constitucionalização do país e avessos às instituições liberais, inclusive aos partidos políticos.

Esse conflito se desenha no próprio governo provisório, devido ao processo de fortalecimento do Tenentismo em seu interior, o que gerou descontentamento em parte dos oligarcas dissidentes apoiadores da revolução. O crescimento político do Tenentismo se verifica quando olhamos para a quantidade de postos importantes do governo ocupados por elementos ligados ao movimento tenentista. A Tabela 1 mostra os ministros do governo provisório até 1935, divididos pelos ministérios que ocupavam e a quais grupos políticos pertenciam.

Como podemos observar na Tabela 1, dos 25 ministros que passaram pelas pastas ministeriais no período de 1930 a 1935, 13 estavam vinculados ao grupo tenentista, um total de 52\%. Em relação aos demais grupos que compunham o governo provisório, seis eram Republicanos Liberais, contabilizando 24\%, cinco eram Oligarcas Dissidentes, contabilizando $20 \%$ e, por fim, um burocrata, que contabiliza 4\%. Assim, mesmo somando esses grupos, o valor não equivale à porcentagem do número de ministérios comandados pelos tenentes. Portanto, a influência política tenentista no governo provisório não pode ser negligenciada.

Esse espaço político preenchido pelos tenentistas no governo provisório fica ainda mais evidente quando olhamos para o quadro de interventore ${ }^{13}$ indicados por Vargas até 1935, como mostramos na Tabela 2.

Como vemos na Tabela 2, de um total de 36 interventores indicados por Vargas, 23 eram vinculados ao grupo dos tenentistas, contabilizando um percentual de 64\%. Em relação aos outros grupos, vemos três interventores ligados aos Republicanos Liberais (9\%), os Oligarcas Dissidentes com cinco interventores $(14 \%)$ e, por fim, três interventores que não estavam vinculados a 
Tabela 1 - Composição Ministerial de 1930-1935

\begin{tabular}{|c|c|c|c|}
\hline Período & Nome & Ministério & Grupo político \\
\hline 1930-1932 & Assis Brasil & Ministro da Agricultura & Republicano Liberal \\
\hline $1932-1934$ & Juarez Távora & Ministro da Agricultura & Tenentista \\
\hline 1934-1937 & Odilon Braga & Ministro da Agricultura & Oligarca Dissidente \\
\hline 1930-1932 & Francisco Campos & Ministro da Educação e Saúde Pública & Oligarca Dissidente \\
\hline 1933-1934 & Washington Pires & Ministro da Educação e Saúde Pública & Oligarca Dissidente \\
\hline 1934-1945 & Gustavo Capanema & Ministro da Educação e Saúde Pública & Tenentista \\
\hline $1930-1931$ & José Maria Whitaker & Ministro da Fazenda & Republicano Liberal \\
\hline 1931-1934 & Osvaldo Aranha & Ministro da Fazenda & Tenentista \\
\hline 1934-1945 & Arthur Costa & Ministro da Fazenda & Burocrata \\
\hline $1930-1931$ & José de Castro & Ministro da Guerra & Tenentista \\
\hline $1932-1933$ & Augusto Cardoso & Ministro da Guerra & Tenentista \\
\hline 1934-1935 & Góis Monteiro & Ministro da Guerra & Tenentista \\
\hline 1930-1931 & Osvaldo Aranha & Ministro da Justiça e Negócios Interiores & Tenentista \\
\hline 1931-1932 & Mauricio Cardoso & Ministro da Justiça e Negócios Interiores & Republicano Liberal \\
\hline $1932-1934$ & Francisco A. Maciel Jr. & Ministro da Justiça e Negócios Interiores & Republicano Liberal \\
\hline 1934-1937 & Vicente Rao & Ministro da Justiça e Negócios Interiores & Republicano Liberal \\
\hline 1930 & José de Noronha & Ministro da Marinha & Tenentista \\
\hline 1930-1931 & Conrado Heck & Ministro da Marinha & Tenentista \\
\hline 1931-1935 & Protógenes Guimarães & Ministro da Marinha & Tenentista \\
\hline $1930-1933$ & Afrânio de Mello Franco & Ministro das Relações Exteriores & Oligarca Dissidente \\
\hline 1934-1937 & José Carlos Soares & Ministro das Relações Exteriores & Republicano Liberal \\
\hline 1930-1932 & Lindolfo Collor & Ministro do Trabalho Comércio e Indústria & Oligarca Dissidente \\
\hline $1932-1934$ & Joaquim Pedro Salgado & Ministro do Trabalho Comércio e Indústria & Tenentista \\
\hline 1934-1937 & Agamenon Magalhães & Ministro do Trabalho Comércio e Indústria & Tenentista \\
\hline 1930-1934 & José Américo de Almeida & Ministro da Aviação e Obras Públicas & Tenentista \\
\hline
\end{tabular}

Fonte: Os autores, a partir do Dicionário Histórico-Biográfico Brasileiro (2008).

${ }^{14}$ Os 4\% restantes são de indivíduos cujos dados suficientes não foram encontrados para classificá-los de acordo com nossa tipologia. Informações sobre como essa classificação foi construída estão presentes no Anexo $B$ Notas Metodológicas. grupos políticos $(9 \%)^{14}$. Assim, novamente somando o grupo dos Republicanos Liberais com o dos Oligarcas Dissidentes e dos sem vínculo político, temos um percentual de apenas $32 \%$, exatamente a metade do valor de interventores tenentistas, dado que revela a força política desse grupo no Governo Provisório. Os dados revelam que os grupos dos tenentes tinham uma posição de participação direta sobre as decisões a serem tomadas naquele momento. Isso fica ainda mais evidente em relação à reorganização partidária ocorrida no período.

Notamos, pela movimentação dos atores políticos, que o projeto partidário do Governo Provisório para o país passava pela criação de uma agremiação partidária nacional, objetivando eliminar o regionalismo que nutria os tradicionais partidos republicanos. Esse pensamento, objetivando combater o regionalismo partidário, era uma visão claramente tenentista como se revela neste trecho do tenentista Paim Vieira transcrito por Souza (1990, pp.66-67),

“[...] Partido é o inimigo nato da harmonia social. Porque 'partido' é um conjunto de indivíduos de interesses semelhantes que disputam a posse do estado para dirigi-lo segundo suas exclusivas conveniências, sem atender aos interesses de mais ninguém (...) [S]ão simples agregados de clãs organizados para a exploração das vantagens do poder; meras associações de interesses privados ou delegações de pequenas oligarquias políticas". 
Tabela 2 - Interventores Indicados por Vargas de 1930 a 1935

\begin{tabular}{|c|c|c|c|}
\hline UF & Interventor & Período no cargo & Grupo político \\
\hline $\mathrm{AC}$ & Francisco P. Assis Vasconcelos & $1930-1934$ & - \\
\hline $\mathrm{AL}$ & Hermilio de Freitas Melro & $1930-1931$ & Tenentista \\
\hline $\mathrm{AL}$ & Tasso de Oliveira Tinoco & $1931-1932$ & Tenentista \\
\hline $\mathrm{AL}$ & Francisco Afonso de Carvalho & 1933-1934 & - \\
\hline $\mathrm{AL}$ & Osman Loureiro de Farias & 1934-1935 & Não pertence a grupos políticos \\
\hline $\mathrm{AM}$ & Álvaro Botelho Maia & $1930-1933$ & Republicano Liberal \\
\hline $\mathrm{AM}$ & Nelson de Melo & 1933-1935 & Tenentista \\
\hline BA & Juracy Magalhães & $1931-1937$ & Tenentista \\
\hline $\mathrm{CE}$ & Roberto Carlos V. C. de Mendonça & $1931-1934$ & Tenentista \\
\hline DF & Adolfo Bergamini & 1930-1931 & Republicano Liberal \\
\hline DF & Pedro Ernesto Batista & $1931-1934$ & Tenentista \\
\hline ES & João Punaro Bley & $1930-1943$ & Tenentista \\
\hline GO & Pedro Ludovico Teixeira & $1930-1934$ & Oligarca Dissidente \\
\hline MA & Lorival Seroa da Mota & $1931-1933$ & - \\
\hline MA & Antônio Martins de Almeida & 1933-1935 & Tenentista \\
\hline MG & Olegário Maciel & $1930-1933$ & Oligarca Dissidente \\
\hline MG & Benedito Valadares & $1933-1945$ & Oligarca Dissidente \\
\hline MT & Artur Antunes Maciel & $1931-1932$ & Tenentista \\
\hline MT & Leônidas Antero de Matos & $1932-1934$ & Oligarca Dissidente \\
\hline PA & Joaquim de Magalhães C. Barata & 1930-1935 & Tenentista \\
\hline PB & Antenor de França Navarro & $1930-1932$ & Civil ligado à Revolução de 30 \\
\hline PB & Gratuliano da Costa Brito & $1932-1934$ & Oligarca Dissidente \\
\hline PE & Carlos de Lima Cavalcanti & $1930-1935$ & Tenentista \\
\hline PI & Landry Sades Gonçalves & $1931-1935$ & Tenentista \\
\hline PR & Mário Alves M. Tourinho & $1930-1931$ & Tenentista \\
\hline PR & Manuel Ribas & $1931-1945$ & Civil ligado à Revolução de 30 \\
\hline RJ & Plínio Casado & $1930-1931$ & Tenentista \\
\hline RJ & Ari Parreiras & $1931-1935$ & Tenentista \\
\hline $\mathrm{RN}$ & Bertino Dutra da Silva & $1932-1933$ & Tenentista \\
\hline $\mathrm{RN}$ & Mário Leopoldo P. da Câmara & 1933-1935 & Civil ligado à Revolução de 30 \\
\hline $\mathrm{RN}$ & Hercolino Carcado & $1931-1932$ & Tenentista \\
\hline RS & Flores da Cunha & 1930-1937 & Tenentista \\
\hline $\mathrm{SC}$ & Ptolomeu de Assis Brasil & $1930-1932$ & Tenentista \\
\hline $\mathrm{SC}$ & Aristiliano Ramos & 1933-1935 & Tenentista \\
\hline SE & Augusto Maynard Gomes & $1930-1935$ & Tenentista \\
\hline SP & João Alberto Lins de Barros & $1930-1931$ & Tenentista \\
\hline SP & Valdomiro Castilho de Lima & $1932-1933$ & Tenentista \\
\hline SP & Armando Sales de Oliveira & 1933-1935 & Republicano Liberal \\
\hline
\end{tabular}

Fonte: Os autores, a partir do Dicionário Histórico-Biográfico Brasileiro (2008).

O projeto tenentista de construção de uma agremiação nacional interessava aos objetivos de Vargas, já que, como argumenta Souza (idem), "os partidos políticos, por serem organizações estaduais, eram considerados mecanismos que haviam contribuído para o fortalecimento do regionalismo, para descentra- 
15 Reuniu vários grupos revolucionários, como a Legião Cívica 5 de Julho, Clube 3 de Outubro, Clube 5 de Julho de São Paulo, União Cívica Brasileira e o Partido Democrático-Socialista.

16 Essa agremiação não apresentava liderança nacional, tampouco uma organização administrativa centralizada; era apenas uma espécie de fórum em que os partidos estaduais do Norte se reuniam para definir estratégias conjuntas de ação coletiva.

${ }^{17}$ Composta pelo Partido Republicano Paulista e pequenos grupos políticos existentes no estado.

18 Facção do PRM controlada pelo ex-presidente Artur Bernardes.
19 Lembrando que esse era um projeto das oligarquias dissidentes do Rio Grande do Sul, que tinham como pivô Assis Brasil, e visavam reformar as instituições liberais, mas manter o sistema político dentro dos parâmetros liberais, aos quais os tenentes eram contra.

${ }^{20}$ Líder oligarca do Rio Grande do Sul e apoiador da revolução de 1932. lização política e, consequentemente, para a perpetuação do poder das oligarquias".

É a partir do descrito acima que podemos entender as várias tentativas feitas na época para a criação de uma agremiação nacional. Vale lembrar aqui a Liga Nacional, a Legião de Outubro e o Clube 3 de Outubro, ainda que nenhuma delas tenha se mantido. Após a Revolução Constitucionalista de 1932, Juarez Távora (líder dos estados do Norte e Nordeste) retoma esse projeto de formar um partido nacional e procura se articular, primeiramente, com as lideranças estaduais do Norte e Nordeste.

Essa iniciativa culmina no Congresso Revolucionário, em novembro de $1932^{15}$, no qual se define o programa do Partido Socialista Brasileiro (PSB) que tinha a pretensão de congregar todos os grupos políticos revolucionários para atuar em uma ação conjunta. No entanto, esse partido não consegue se organizar nacionalmente e se estabelecer como agremiação nacional. A última tentativa nesse sentido ocorre no ano de 1933, mas, agora, com outra lógica de organização. Na convenção revolucionária realizada em abril de 1933 é criada a União Cívica Nacional (UCN) que, na realidade, era uma confederação nacional com a responsabilidade de congregar os diversos partidos estaduais ${ }^{16}$ criados pelos interventores. Essa tentativa, entretanto, fracassou, já que também não conseguiu a adesão dos partidos do Sul e sua atuação ficou restrita às regiões Norte e Nordeste.

A estratégia de criação de um partido nacional não se concretizou e, paralelamente a esse fracasso, deflagra-se, no dia 9 de julho de 1932, a Revolução Constitucionalista, que representava o desfecho da insatisfação por parte de grupos oligárquicos apoiadores da Revolução de 1930, pelo crescente poder político que os tenentes vinham conquistando no Governo Provisório. Esse fato se revela no desenho do conflito revolucionário: de um lado, temos as frações oligárquicas do Centro-Sul (Frente Única Paulista ${ }^{17}$, Facção bernardista do $\mathrm{PRM}^{18}$ e a Frente Única Gaúcha) ávidas por reconquistar o poder perdido, às quais se radicalizam e se unem à principal oposição do governo provisório, a oligarquia paulista; e de outro lado, o Governo Provisório, os tenentes e os estados do Norte e Nordeste.

Embora o desfecho desse conflito tenha sido a vitória do governo, Vargas percebe que não seria possível dar continuidade ao seu projeto político tendo como base de apoio somente os tenentes e as oligarquias do Norte e do Nordeste. Alijando as principais oligarquias, as do Rio Grande do Sul, Minas Gerais e São Paulo, Vargas passa, então, a se movimentar no sentido de esvaziar o movimento tenentista levando o país à principal demanda dos grupos oligárquicos: a constitucionalização do país. Para tanto, Vargas dá continuidade ao processo de elaboração do Código Eleitoral de $1932^{19}$ e estabelece, para 5 de maio de 1933, as eleiçõos para a Constituinte.

A intenção de Vargas de atender a demanda das antigas oligarquias, como também a das oligarquias dissidentes, fica clara neste trecho da carta escrita a Borges de Medeiros ${ }^{20}$ e transcrita por Silva (1967, p.212): “O apoio do Rio Grande é a condição da minha permanência no governo[...]. [E]u quero começar a reconstitucionalização, mas tenho que agir lentamente por causa de certos elementos militares".

Assim, após o término da revolução paulista de 1932, Vargas prende e exila os principais líderes do movimento, como Arthur Bernardes, Borges de Medeiros, Maurício Cardoso, Lindolfo Collor e inicia o processo de preparação política para as eleições da Constituinte de 1933, com uma nova estratégia de organização partidária, que consistia na utilização dos interventores como peças-chave na cooptação de grupos políticos regionais, visando a construção 
${ }^{21}$ Aliado de Vargas.

${ }^{22}$ Cidade próxima à fronteira argentina em que os exilados se encontravam.
${ }^{23}$ Grande rival político de Artur Bernardes. de partidos políticos estaduais comprometidos com o Governo Provisório. Fica claro, observando a movimentação de Vargas, o abandono do "plano A" organização de um partido nacional - e a adoção de um "plano B", a construção de agremiações partidárias estaduais que o apoiassem, como demonstra o trecho abaixo,

"[...] Naquela época o governo interessado em demolir as estruturas dos partidos republicanos estaduais veio a incentivar a criação de novos partidos regionais que surgissem com o compromisso explícito com o objetivo de defender a revolução de 1930” (Dicionário Histórico-Biográfico 2008, p. 4283).

Apesar de Vargas optar por manter a atuação partidária regional, tal fato não corresponde a um retrocesso da situação partidária existente na Primeira República. A criação de partidos estaduais se dava em outros termos, uma vez que a estratégia de Vargas era a de institucionalizar o conflito político que havia se radicalizado em conflito armado. Mantido o cenário anterior à revolução paulista, Getúlio temia a ocorrência de um novo conflito, já que as conspirações por parte dos opositores estavam bastante ativas, como demonstra esse trecho da carta de Gregório da Fonseca ${ }^{21}$, em Rosalina ${ }^{22}$, e transcrita por Silva (1968, pp.58-59): "Cuidado com o armamento clandestino em São Paulo(...) [S]e a revolução paulista recomeçar com os armamentos que dizem eles chegarem a São Paulo a vitória paulista é certa".

Nesse momento, a opção mais racional para o chefe do Governo Provisório era abrir espaço político para a atuação da oposição, a fim de moderar o conflito político. Essa ação passava pela construção de um cenário partidário plural e de relativa competitividade (controlada), devido à criação de partidos políticos pelos interventores, cooptando grupos políticos regionais que se comprometeriam com o Governo Provisório. Isto é, a competição política seria controlada pelo governo, pois seus partidos, nesse momento, eram muito mais fortes politicamente que os de oposição, especialmente por terem sido criados pelos interventores cooptando grupos regionais "fisiológicos", ou seja, grupos que sempre estavam do lado situacionista, fato que atribuía elevado capital político a esses partidos, tornando a disputa assimétrica.

A estratégia de reorganização partidária via interventores estaduais é observada em todos os estados brasileiros. No Rio Grande do Sul, Getúlio indica para assumir a interventoria seu amigo Flores da Cunha, que aproveita a desarticulação política da Frente Única Gaúcha (PRR-PL) - devido ao exílio de seus principais líderes, como Borges de Medeiros - e articula, com grupos provenientes desses partidos, a formação de um partido que respeitasse os princípios tradicionais do estado, mas que, em contrapartida, teria comprometimento com o governo central. Assim, após firmarem acordo sobre os principais pontos de seu interesse, fundam o Partido Republicano Liberal (PRL), que viria a ser um braço do Governo Provisório, no estado e na Constituinte, graças à liderança do interventor.

Dinâmica parecida ocorre nos demais estados. Em Minas Gerais, Getúlio, com o objetivo de enfraquecer politicamente a ala bernardista do PRM, nomeia como interventor Olegário $\mathrm{Maciel}^{23}$, em 1931, iniciando, assim, um processo de avanço sobre as tradicionais oligarquias, com a criação da Legião de Outubro, que passa a perseguir as tradicionais forças políticas do PRM ligadas a Artur Bernardes. Essa estratégia, radical à primeira vista, surtiu efeito, pois o PRM começa a perder espaço político dentro do estado. No entanto, essa mesma radicalização provocou uma reação das oligarquias que passaram a se aglutinar em torno da facção bernardista e esvaziar a força política da Legião que, por fim, acabou fracassando.

A próxima estratégia seria a de aglutinar, em torno de um único grupo político, as duas facções -os legionários e os bernardistas. Isso se concretizou 
${ }^{24}$ Integrada pelos ex-combatentes da Revolução Constitucionalista de 1932 .

${ }^{25}$ Paulista ligado aos banqueiros e industriais e bastante aceito nos grupos políticos regionais. em fevereiro de 1932 com a criação do Partido Social Nacionalista (PSN). No entanto, estoura a Revolução Constitucionalista em 1932 e o pacto é desfeito pela facção bernardista que apoia os revolucionários. Passada a revolução, inicia-se o período decisivo de reaglutinação política de Minas Gerais, Rio Grande do Sul, São Paulo, entre outros estados. Artur Bernardes é exilado e sua facção é praticamente extinta. E Olegário Maciel, como interventor, inicia o período de novas articulações com os grupos políticos mineiros, visando a uma reorganização partidária tendo em vista a Constituinte. Surge, assim, o Partido Progressista (PP), que viria a ser o partido de apoio ao Governo Provisório no estado e na Assembleia Nacional Constituinte (ANC).

No estado de São Paulo, do período de 1930 até a Revolução Constitucionalista de 1932, observa-se um processo de extrema radicalização das forças políticas, a qual leva o PD a romper com a aliança liberal e se aproximar de seu grande rival no estado, o Partido Republicano Paulista (PRP); entrando, assim, em conflito com o Governo Provisório, que começava a querer fazer incursões políticas no estado. Passada a Revolução de 1930, Getúlio nomeia como interventor Waldomiro Lima, que fica incumbido da difícil tarefa de pacificar e fazer alianças com os mais diversos grupos políticos de São Paulo (como os ligados à cafeicultura, ao empresariado do comércio, ao da indústria e, também, ao operariado), a fim de arregimentar uma substancial base política para o governo. Em meio a essa dinâmica é criado o anteriormente citado Partido Socialista Brasileiro (PSB), organizado em 1932 pelo interventor e que visava atingir as classes trabalhadoras através da organização dos sindicatos. É também criado o Partido da Lavoura (PL), que buscava conseguir o apoio dos trabalhadores da lavoura via sindicato. Essas duas tentativas, no entanto, fracassaram por não conseguirem adesão que satisfizesse essas camadas sociais.

Do lado da oposição ao interventor, o PD, PRP e a federação dos voluntários $^{24}$ se unem e criam a Chapa Única por São Paulo Unida, visando enfraquecer, ainda mais, o interventor e obter apoio político-eleitoral para disputar as eleições da Constituinte. A conturbada política paulista só é contornada por Getúlio durante a ANC quando este nomeia Armando Sales de Oliveira $^{25}$ como interventor, o qual consegue elaborar uma aliança com as forças políticas do estado e juntos fundam o Partido Constitucionalista (PC), com o compromisso de apoio ao governo central.

Na região Norte e Nordeste o processo de reorganização político-partidária ocorre de maneira bem mais tranquila quando comparado aos estados acima citados, isto é, os interventores ficam encarregados de criar um partido estadual que aglutinasse (em torno deste) as forças políticas dos respectivos estados e que estas apoiassem o Governo Provisório. Em 18 de fevereiro de 1933 é fundada a União Cívica Nacional (UCN), que correspondia a uma coligação de todos os partidos criados pelos interventores. Esse objetivo é alcançado com sucesso, tendo sido obtida a adesão de todos os estados do Norte e do Nordeste, o que conferiu ao Governo Provisório boa penetração nessas regiões e o apoio delas na Constituinte.

A Tabela 3 mostra a nova configuração partidária, por estado, após esse processo de rearranjo político na política brasileira da época.

\section{IV.1 Cenário eleitoral e partidário nos pleitos de 1933 e 1934}

Antes de analisarmos a nova configuração do sistema partidário posterior à adoção do Código Eleitoral de 1932, faz-se necessário ressaltar o cenário político-partidário na Primeira República. A diferença mais patente entre o período anterior e posterior a 1932 está na diversificação partidária e na presença de partidos oposicionistas na representação legislativa do país. A 
Tabela 3 - Configuração do Sistema Partidário Pré-Constituinte de 1933

\begin{tabular}{|c|c|c|}
\hline UF & Partido & Posição política \\
\hline $\mathrm{AC}$ & Legião Autonomista Acreana & Governo \\
\hline $\mathrm{AC}$ & Lista Chapa Popular & Oposição \\
\hline $\mathrm{AL}$ & Partido Nacional de Alagoas & Governo \\
\hline AL & Partido Republicano de Alagoas & Oposição \\
\hline $\mathrm{AM}$ & União Cívica Amazonense & Governo \\
\hline $\mathrm{AM}$ & Coligação Trabalhista Liberal & Oposição \\
\hline BA & Lista a Bahia ainda é a Bahia & Oposição \\
\hline BA & Partido Social Democrático da Bahia & Governo \\
\hline $\mathrm{CE}$ & Liga Eleitoral Católica & Oposição \\
\hline $\mathrm{CE}$ & Partido Social Democrático & Governo \\
\hline $\mathrm{DF}$ & Partido Democrático & Oposição \\
\hline DF & Partido Economista do Brasil & Oposição \\
\hline $\mathrm{DF}$ & Partido Autonomista do Distrito Federal & Governo \\
\hline ES & Partido da Lavoura & Oposição \\
\hline ES & Partido Social Democrático do Espírito Santo & Governo \\
\hline GO & Partido Social Republicano de Goiás & Governo \\
\hline GO & Coligação Libertadora & Oposição \\
\hline MA & Partido Republicano do Maranhão & Oposição \\
\hline MA & União Republicana Maranhense & Oposição \\
\hline MA & Partido Social Democrático do Maranhão & Governo \\
\hline MT & Partido Constitucionalista & Oposição \\
\hline MT & Partido Liberal Mato-Grossense & Governo \\
\hline MG & Partido Republicano Mineiro & Oposição \\
\hline MG & Partido Progressista & Governo \\
\hline PA & Partido Liberal do Pará & Governo \\
\hline PA & Partido Republicano Conservador & Governo \\
\hline PA & Frente Única Paraense & Oposição \\
\hline PB & Partido Progressista da Paraíba & Governo \\
\hline $\mathrm{PB}$ & Partido Republicano Libertador & Oposição \\
\hline PR & Partido Social Democrático & Governo \\
\hline PR & Partido Liberal Paranaense & Oposição \\
\hline PE & Partido Republicano Social & Oposição \\
\hline PE & Partido Social democrático de Pernambuco & Governo \\
\hline PI & Partido Nacional Socialista & Governo \\
\hline PI & Lista Hugo Napoleão & Governo \\
\hline RJ & Partido Socialista Fluminense & Indefinido \\
\hline RJ & Partido Republicano Fluminense & Oposição \\
\hline RJ & Partido Popular Radical & Governo \\
\hline RJ & União Progressista Fluminense & Governo \\
\hline $\mathrm{RN}$ & Partido Popular do Rio Grande do Norte & Oposição \\
\hline $\mathrm{RN}$ & Partido Social Nacionalista & Governo \\
\hline RS & Partido Republicano Liberal & Governo \\
\hline RS & Chapa Única & Oposição \\
\hline
\end{tabular}


SC

SC

SP

SP

SP

SE

SE
Col. P. Republicano/Leg. Republicana

Partido Liberal Catarinense

Legenda Chapa Única

Partido Socialista Brasileiro

Partido da Lavoura

Lista Liberdade e Civismo

União Republicana de Sergipe
Oposição

Governo

Oposição

Governo

Governo

Governo

Indefinido

Fontes: Os autores, com base no Boletim Eleitoral de 1933 (TSE 1936) e no Dicionário Histórico-Biográfico Brasileiro (2008).

Primeira República se caracteriza por um monopólio governista, enquanto o período posterior ao Código de 1932 revela-se partidariamente mais plural e eleitoralmente competitivo. O Gráfico 1 demonstra a distribuição partidária dos candidatos eleitos no período entre 1900 e 1930 (média percentual) para a Câmara dos Deputados, tendo como referência o domínio de partidos governistas.

De acordo com Zulini \& Ricci (2014), o Gráfico 1 revela que entre 1900 e 1930 a grande maioria dos parlamentares eleitos na Primeira República são de partidos governistas. Apenas o Distrito Federal apresenta uma representação dividida, tendo o partido governista, em média, um pouco mais de $50 \%$ das cadeiras. A média para o período, no entanto, revela que aproximadamente $85 \%$ da Câmara dos Deputados era composta por partidos estaduais governistas. Isso é, uma situação de monopólio partidário estadual e praticamente de ausência de grupos opositores na arena parlamentar durante o primeiro período republicano do país.

As diferenças marcantes na configuração do sistema partidário referente aos pleitos de 1933 e 1934 - diversificação partidária, competição política e representação oposicionista - comparadas à situação partidária-eleitoral da Primeira República, foram observadas na Tabela 3, e são reforçadas nos Gráficos 2, 3 e 4. Esses gráficos revelam o aumento no número de partidos políticos na busca por representação institucional.

O Gráfico 2 revela que o monopólio dos partidos republicanos estava minado já nas eleições estaduais de 1933. Dos 22 estados da federação consi-

Gráfico 1 - Representação governista na Câmara dos Deputados (1900-1930) (\%)

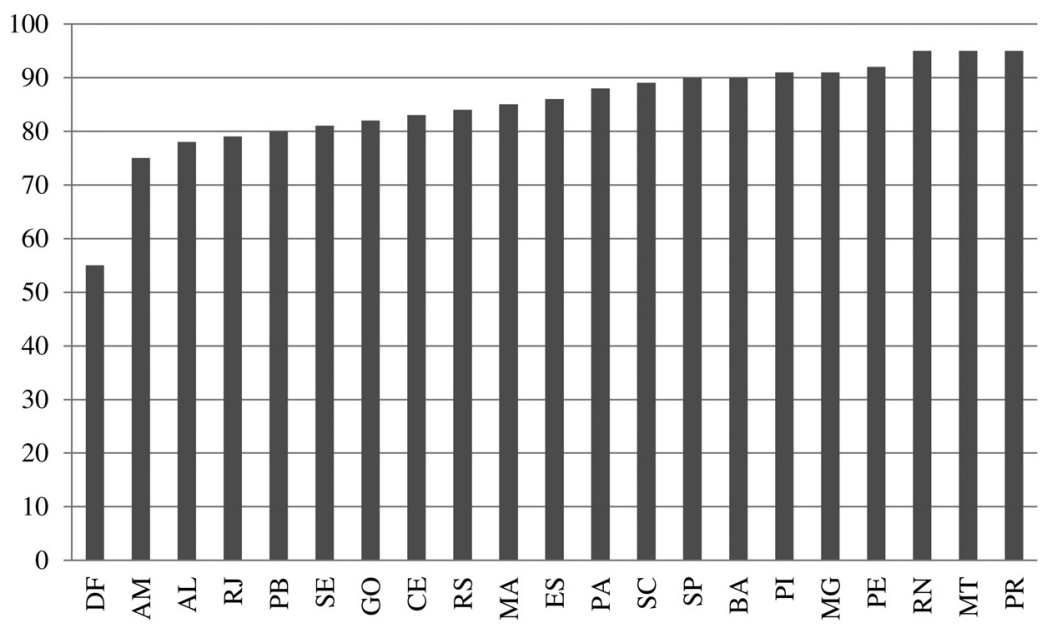

Fonte: Zulini e Ricci (2014, p.7). 
Gráfico 2 - Número de partidos representados na Constituinte de 1933 (por estado)

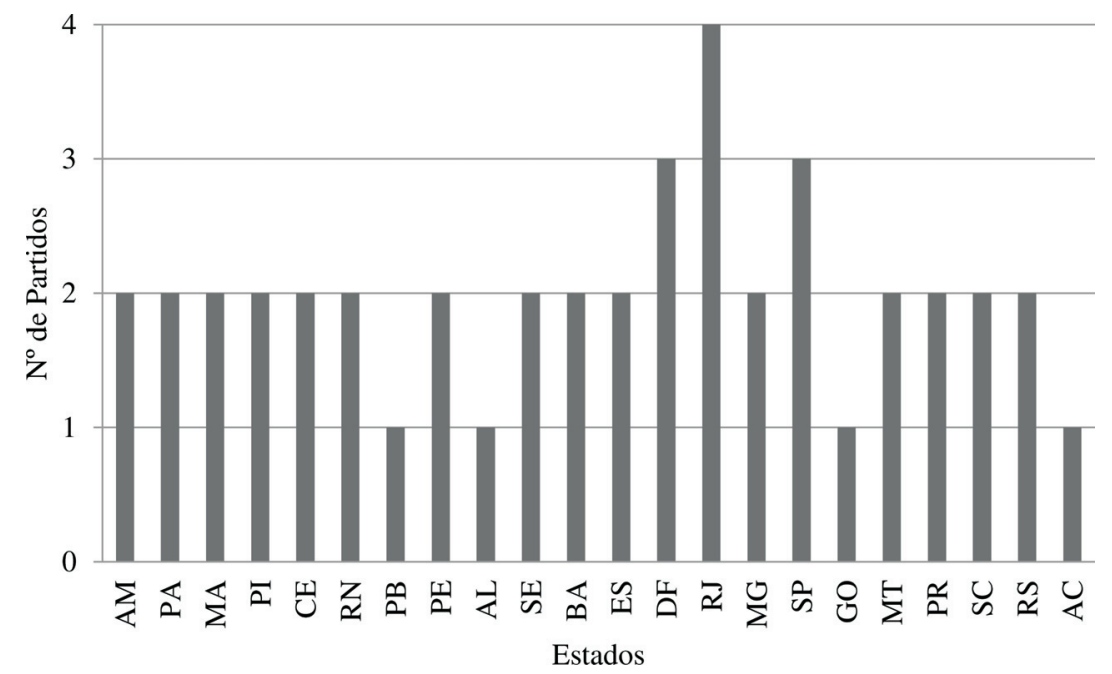

Fonte: Os autores, a partir do Boletim Eleitoral de 1933 (TSE 1936).

Gráfico 3 - Número de partidos com representação na Câmara Federal do Brasil em 1934 (por estado)

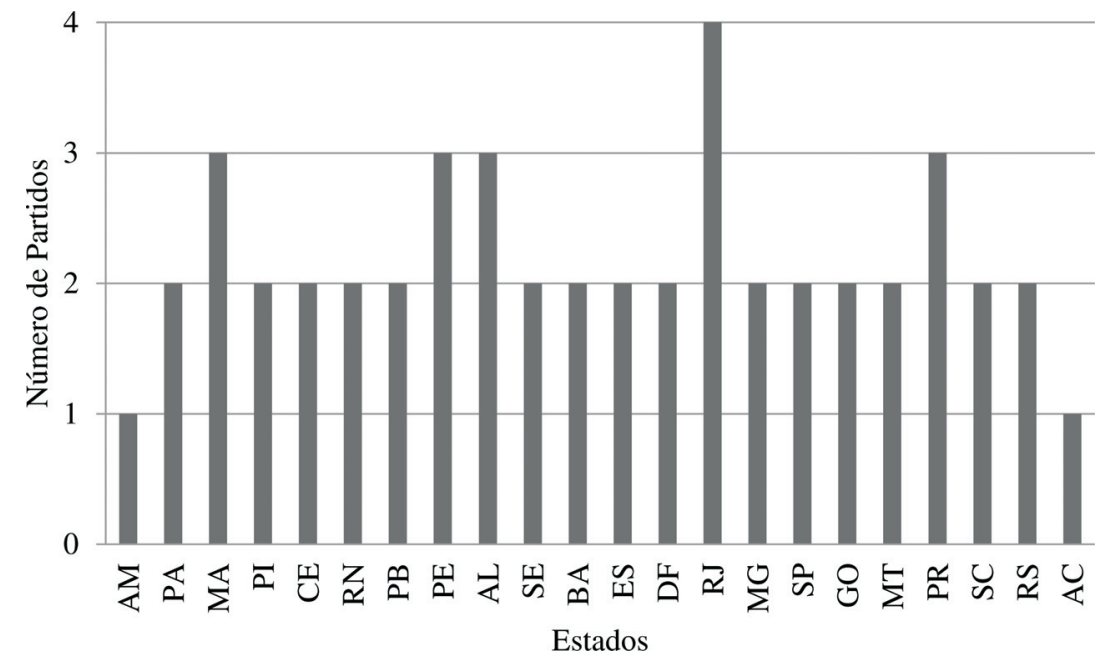

Fonte: Os autores, com base no Boletim Eleitoral 1933-34 (TSE 1936).

derados, apenas quatro tiveram bancadas monopartidárias no pleito de 1933: Paraíba, Alagoas, Goiás e Acre. Essa lógica política também se evidencia nas eleições de 1934.

O Gráfico 3 também indica o colapso da monopolização da política brasileira no período analisado em nível federal. Dos 22 estados da federação com representação na Câmara Federal do país em 1934, somente o Amazonas e o Acre possuíam um cenário monopartidário. Todos os outros estados tinham representação com dois ou mais partidos, ou seja, apresentavam bancadas plurais. O estado do Rio de Janeiro é o mais multipartidário, com o maior número de partidos (quatro) na câmara legislativa. O Maranhão, Pernambuco, Alagoas e Paraná estão representados com três partidos. O mesmo se verifica na representação das Constituintes estaduais de 1934 (ver Gráfico 4).

O Gráfico 4 revela que a pluralidade política também esteve presente no nível regional. Dos 21 estados que realizaram eleições para a constituinte 
Gráfico 4 - Número de partidos com representação nas Câmaras Estaduais em 1943 (por estado)

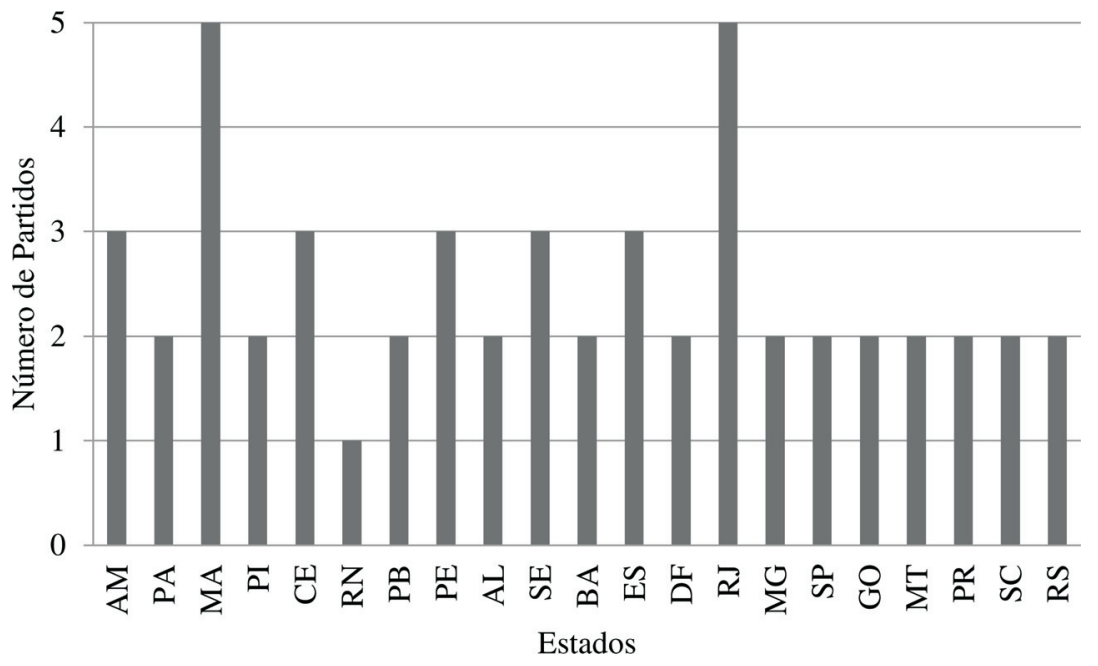

Fonte: Os autores, com base no Boletim Eleitoral 1933-34 (TSE 1936).

${ }^{26}$ O Acre não realizou eleições para Assembleia Constituinte. Por essa razão, não está presente no Gráfico 3

${ }^{27}$ Para mais informações, conferir o Anexo B - Notas Metodológicas.
${ }^{28}$ Os valores contidos no gráfico resultaram da média dos valores obtidos no pleito da Constituinte de 33 e nas eleições de outubro de 1934 . estadual - representação estadual - somente o Rio Grande do Norte possuía um cenário de representação unânime (com apenas um partido) ${ }^{26}$. Todos os outros estados possuíam representação partidária plural, com dois ou mais partidos. $\mathrm{O}$ Maranhão e o Rio de Janeiro tinham as câmaras estaduais mais plurais (cada uma com representação de cinco partidos). Observamos, portanto, ao longo das três eleições realizadas após a Revolução de 1930, que o sistema político brasileiro se tornou mais plural e, se comparado à situação anterior, de monopólio político dos partidos republicanos, demonstra um claro processo de quebra da monopolização partidária.

No entanto, poder-se-ia alegar que os dados apresentados não revelam qualquer sinal de colapso da monopolização da política no Brasil. Isso porque não identificam a presença de partidos de oposição. Sendo assim, talvez seja possível um cenário aparentemente multipartidário, porém, em que não existam partidos de oposição ou, no caso em que estes estão presentes, à oposição não é permitido alcançar a representação. Com isso em mente, nós comparamos nossos dados a novas informações extraídas do Centro de Pesquisa e Documentação de História Contemporânea do Brasil (CPDOC-FGV) ${ }^{27}$. A partir dessas novas informações, somos capazes de identificar para as legislaturas federal e estaduais em 1933 e 1934 não só o número de partidos em cada estado, mas também identificar a que lado pertencia a maioria legislativa (se ao governo ou à oposição), bem como revelar a porcentagem da representação minoritária nas câmaras federal e estaduais.

Primeiramente, o Gráfico 5 mostra a média percentual de cadeiras nos pleitos realizados no período ${ }^{28}$. Notamos que o alinhamento partidário mostra uma ainda grande maioria governista, com uma média percentual de 67,5\%, o que sugere uma continuidade do situacionismo tal como ocorria na Primeira República. A diferença notória é que a oposição, diferente do que ocorria até então, obtém um importante espaço nos pleitos ocorridos em 1933 e 1934, com uma média percentual de 31,5\%. Assim, podemos considerar que o sistema político brasileiro aumentou seu nível de competição e representação políticas. Para demonstrar que o quadro partidário brasileiro se transformou e se tornou mais competitivo e plural, identificamos, na Tabela 4 , quais forças venceram as eleições em cada estado. 
Gráfico 5 - Resultados eleitorais dos pleitos de 1933 e 1934 (médias percentuais)

घhoverno = Oposição $\quad$ Indefinido

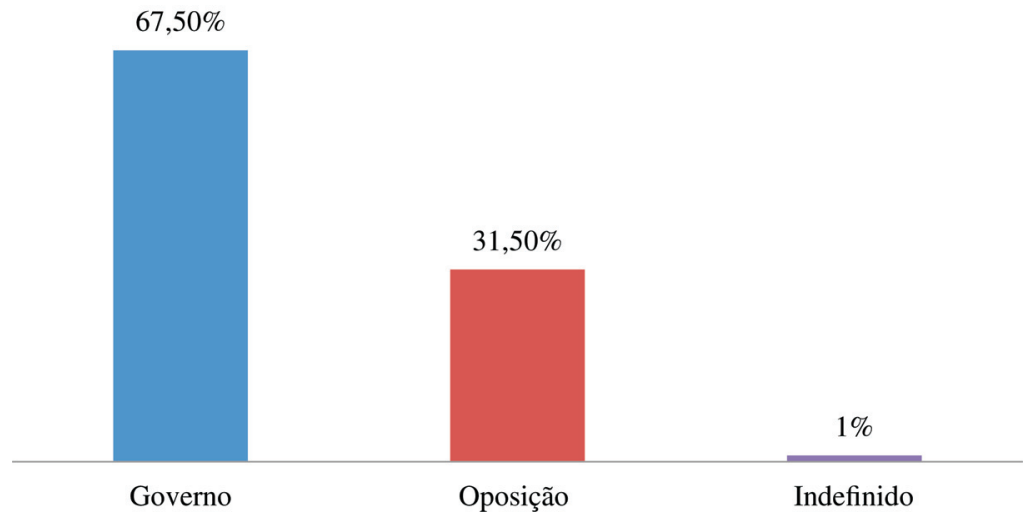

Fonte: Os autores, com base no Boletim Eleitoral de 1933 e 1934 e no Dicionário Histórico-Biográfico Brasileiro (2008).

Observamos, na Tabela 4, que o governo ainda adquiriu grande vantagem sobre a oposição nas eleições de 1933, pois dos 22 estados da Federação, em 17 deles o governo conseguiu a maioria das cadeiras, mas em pelo menos cinco estados a oposição saiu vitoriosa e obteve a representação política: no Acre, em que a Chapa Popular, agremiação de oposição ao governo, obteve as duas cadeiras destinadas ao estado, vencendo o partido situacionista, Legenda Autonomista Acreana; no Ceará, onde a Liga Eleitoral Católica conseguiu seis das dez cadeiras destinadas ao estado, tendo a situação, através do Partido Social Democrático do Ceará, obtido as quatro cadeiras restantes; no Maranhão, em que ocorreu a emergência de dois partidos de oposição, a União Republicana Maranhense, que conquistou duas cadeiras de um total de sete e o Partido Republicano do Maranhão, que obteve as cinco cadeiras restantes, tendo a oposição vencido o partido situacionista, denominado Partido Social Democrático do Maranhão; no Rio Grande do Norte, onde a oposição, por meio do Partido Popular do Rio Grande do Norte, obteve três cadeiras de um total de quatro, tendo vencido o partido da situação, denominado Partido Social Nacionalista, que ficou com a vaga restante; e, por fim, a oposição venceu em São Paulo, estado que foi histórico adversário político de Vargas e que, por meio da Chapa Única, conseguiu obter 17 das 22 cadeiras, vencendo, com folga, os apoiadores de Vargas, que se dividiram em dois partidos, o Partido da Lavoura e o Partido Socialista Brasileiro, tendo o primeiro, conquistado duas cadeiras e o segundo, três.

Chama atenção na Tabela 4 o fato de a oposição, pela primeira vez, obter maioria em cinco estados (como supracitados, Acre, Ceará, Maranhã, Rio Grande do Norte e São Paulo), fato este impensável na Primeira República. Embora encontremos referências na literatura à respeito da abertura da representação minoritária (Franco 1974; Souza 1974), o estudo de Nunes Leal (1975, p.234) é o único no qual as alternâncias de poder em alguns estados são relatadas (embora o autor não apresente dados e não indique os estados nos quais as oposições consagraram-se vitoriosas nos pleitos).

Cenário parecido ocorre nas eleições para a Câmara Federal e para as Constituintes Estaduais em 1934, onde observamos o governo com uma ainda ampla vantagem em relação à oposição. Mas esta, mais uma vez, encontra espaço de atuação no novo sistema político brasileiro (ver Gráficos 6 e 7). 
Tabela 4 - Resultado Eleitoral (número de cadeiras conquistadas) por Estado na Constituinte de 1933

\begin{tabular}{lcccc}
\hline UF & Governo & Oposição & Total & Maioria \\
\hline AC & & 2 & 2 & Oposição \\
AL & 6 & 6 & Governo & \\
AM & 4 & & 4 & Governo \\
BA & 19 & 3 & 22 & Governo \\
CE & 4 & 6 & 10 & Oposição \\
DF & 6 & 3 & 10 & Governo \\
ES & 4 & & 4 & Governo \\
GO & 4 & 4 & Governo & \\
MA & & 7 & 7 & Oposição \\
MG & 30 & 6 & 36 & Governo \\
MT & 3 & 1 & 4 & Governo \\
PA & 7 & 7 & Governo & \\
PB & 5 & & 5 & Governo \\
PE & 15 & 2 & 17 & Governo \\
PI & 4 & & 4 & Governo \\
PR & 3 & 1 & 4 & Governo \\
RJ & 11 & 6 & 17 & Governo \\
RN & 1 & 3 & 4 & Oposição \\
RS & 13 & 3 & 16 & Governo \\
SC & 3 & 1 & 4 & Governo \\
SE & 4 & & 4 & Governo \\
SP & 5 & 17 & 22 & Oposição \\
Total & $\mathbf{1 5 1}$ & $\mathbf{6 1}$ & $\mathbf{2 1 2}$ & \\
\hline Fin & & & & \\
\hline
\end{tabular}

Fonte: Os autores, a partir dos boletins eleitorais de 1933 e 1934 (TSE 1936) e no Dicionário-Histórico Biográfico Brasileiro (2008).

A primeira informação que chama atenção nos Gráficos 6 e 7 é que em apenas dois estados (Acre e Sergipe) encontramos câmaras unânimes. E no caso do Acre, tanto em nível federal, quanto em nível estadual, o partido de oposição conquistou todas as cadeiras disponíveis. No Sergipe se deu o oposto, todas as cadeiras disponíveis para o estado foram conquistadas por partidos do governo. Em todos os outros estados podemos observar a presença de representação da oposição em ambos os níveis estadual e federal. Mais do que isso, de acordo com o Gráfico 6, em seis estados (Acre, Ceará, Maranhão, Mato Grosso, Rio de Janeiro e Santa Catarina), a maioria legislativa estadual é composta pela oposição. Também em seis estados (Acre, Ceará, Maranhão, Mato Grosso, Rio de Janeiro e Rio Grande do Norte) a maioria das cadeiras disponíveis no legislativo federal é composta pela oposição. Isso significa não só a derrota do governo em algumas das eleições em 1934, como também que o governo aceitou passar o cargo político ao adversário.

Por fim, é importante notar a importância da eleição para as constituintes estaduais, uma vez que dela é que sairiam os futuros governadores de estados. De acordo com o Gráfico 7, ocorreram eleições para as constituintes estaduais em vinte estados da Federação, e desses, o governo saiu vitorioso (obteve maioria) em 14 estados e a oposição, como observado anteriormente venceu em seis deles. Desse modo, é possível afirmar que o cenário político eleitoral 
Gráfico 6 - Representação na Câmara Federal Brasileira em 1934 (percentual das cadeiras conquistadas)

Governo $\square$ Oposição

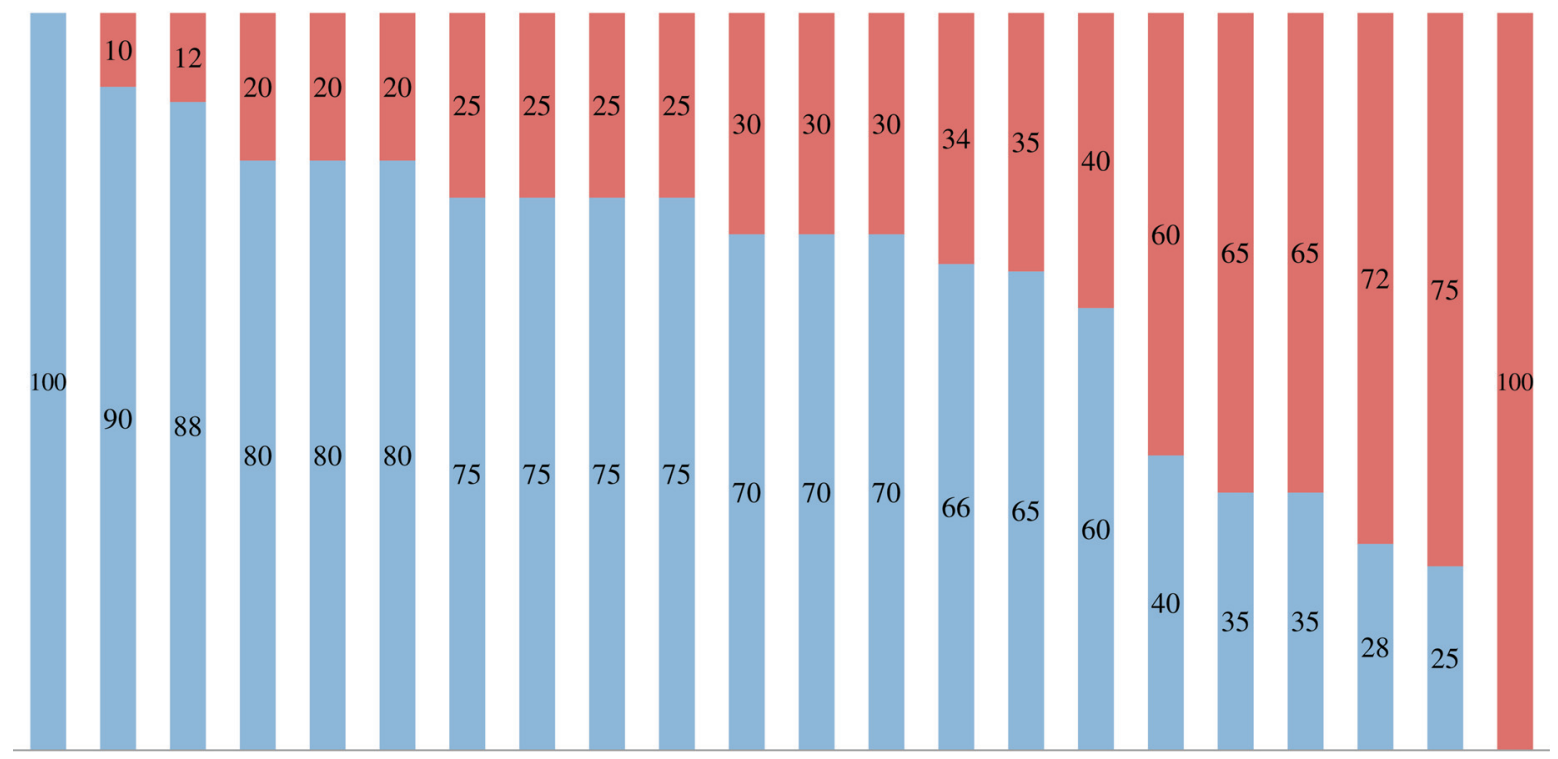

SE PB AL DF PE PI AM ES GO PA BA MG RS PR SP RN RJ CE SC MA MT AC

Fonte: Os autores, com base no Dicionário Histórico-Biográfico Brasileiro (2008) e TSE Brasil (1936).

Gráfico 7 - Representação nas Câmaras Estaduais em 1934 (percentual das cadeiras conquistadas)

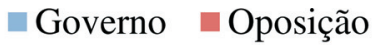

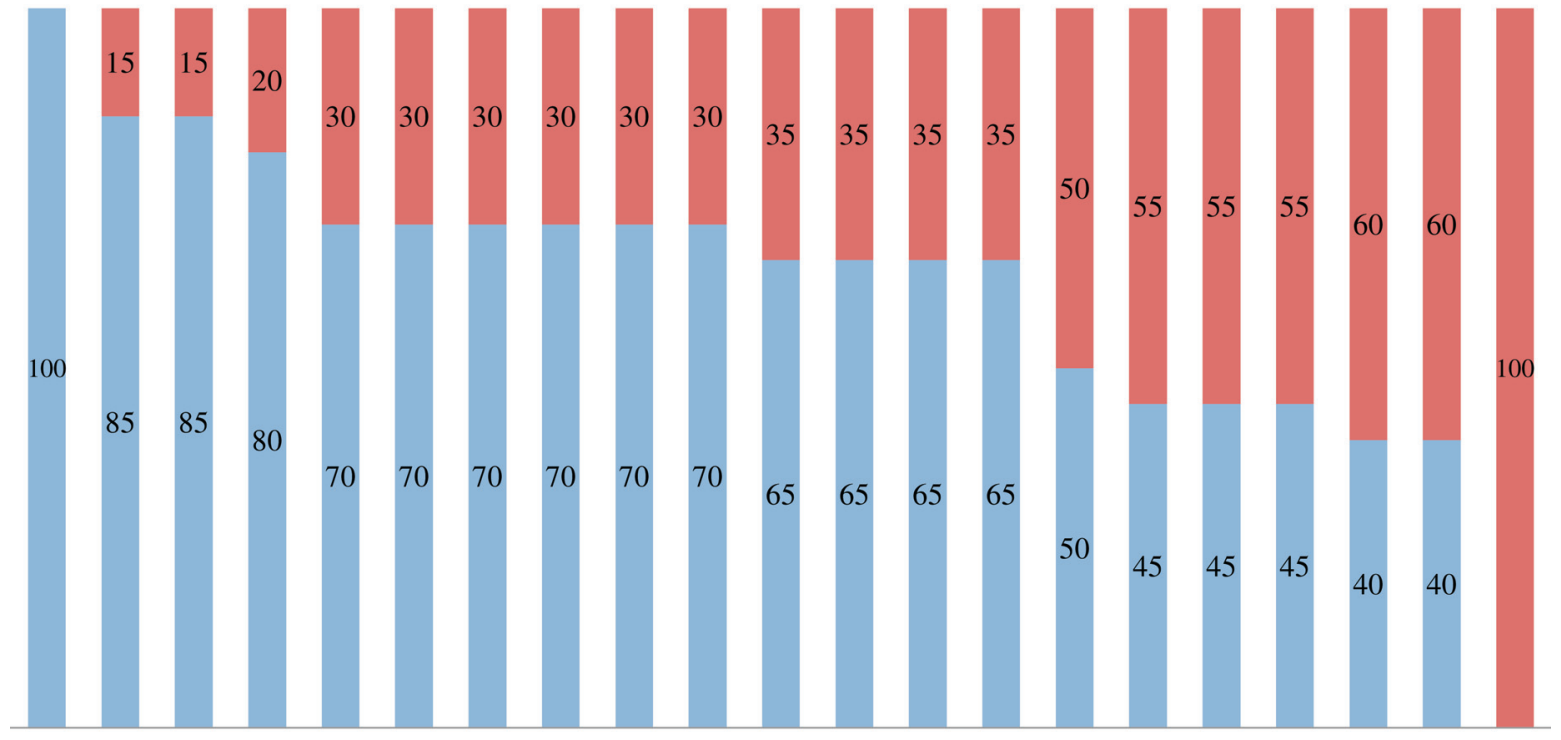

SE AL PB AM BA MG PA PE PI PR ES GO RS SP SC CE MA RN MT RJ AC

Fonte: Os autores, com base no Dicionário Histórico-Biográfico Brasileiro (2008) e TSE Brasil (1936).

brasileiro se apresentou estável nas eleições aqui analisadas. Mais do que isso, é de substancial importância notar que a oposição teve espaço no cenário político. Mesmo sendo pequena, ela conseguiu vitórias em estados importantes, o que revela um sistema político com uma competição política institucionalizada, ainda que baixa, mas com potencial para crescimento. 


\section{Conclusões}

É conhecido e bastante difundido que as eleições praticadas no Brasil entre 1945 e 1964 - período conhecido como primeira experiência democrática do país - foram marcadas pela abertura da competição política e pelo sucesso da oposição nas urnas (Schmitt 2000; Gomes 2009; Limongi 2012; Braga 2013). No entanto, sempre foi tomado como certo pela literatura que esse sucesso não poderia ter ocorrido antes desse período. Ao questionarmos a singularidade desse momento, e a partir do uso de novos dados, chegamos a evidências de que mais de dez anos antes deste período, precisamente em 1933 e 1934, a oposição em praticamente todos os estados do país alcança representação, tanto no Congresso como nas Câmaras Estaduais. E em alguns desses estados a oposição consagra-se como poder majoritário, e a ela sendo permitido ocupar o cargo político. Em suma, o modus operandi governista e monopartidário da Primeira República, descrito pela literatura especializada, parecia dar sinais claros de desestruturação no período Pós-1930.

De modo a compreender o porquê dessas alterações presentes no quadro partidário no período em destaque, dividimos a nossa análise em dois momentos: Na relação entre elites políticas e a construção de uma nova ordem política-institucional no país, e nos efeitos de mudanças institucionais sobre a competição e representação políticas. Dito de outra forma, delineamos o jogo político e suas consequências em relação às decisões tomadas pelo Governo Provisório e apresentamos os efeitos da reforma das instituições eleitorais a partir da adoção do Código Eleitoral de 1932, particularmente nos pleitos de 1933 e 1934.

Ao longo do trabalho, esses dois momentos foram desenvolvidos. O primeiro foi abordado na tentativa de compreender as estratégias dos atores políticos ao reformarem as regras eleitorais, a fim de entender qual efeito que os agentes políticos esperavam das novas instituições eleitorais sobre o sistema político brasileiro e sobre a lógica política derivada dele; o segundo foi desenvolvido buscando compreender a reconfiguração do quadro partidário e eleitoral brasileiro pós-1930.

De acordo com a literatura corrente sobre o tópico, Getúlio e aliados assumem o poder em 1930 e apresentam, como prioridade de suas agendas políticas, a moralização do processo eleitoral brasileiro através da reforma das instituições eleitorais, visando eliminar práticas políticas recorrentes na Primeira República, como as fraudes, a violência contra o eleitor, o monopólio político dos partidos republicanos, entre outras. De acordo com a nossa hipótese complementar, o objetivo acima não foi o único a nortear as preferências dos atores da revolução, pois a eles se apresentavam, como grandes inimigos políticos, as antigas oligarquias e a estrutura político-jurídica e burocrática que as mantinham no poder. Nesse sentido, o Código Eleitoral de 1932 foi também condição sine qua non para o enfraquecimento político dessas oligarquias, na medida em que suas reformas atuavam sobre as três fontes que abasteciam o poder delas: a prática da fraude, o controle sobre o voto do eleitor e a hegemonia política dos partidos republicanos. Inovações institucionais contidas no Código de 1932 permitiram a quebra da hegemonia política dos partidos republicanos através da ampliação representativa de opiniões (possibilitou acesso de pequenos partidos às arenas decisórias federais) e evitou que os partidos republicanos obtivessem vitórias unânimes.

Escolhas institucionais como o voto secreto, a representação proporcional (por meio do sistema eleitoral misto) e a criação da Justiça Eleitoral provocaram efeitos negativos sobre as oligarquias (como a diminuição dos seus recursos políticos) e ampliou a influência dos atores revolucionários sobre o sistema 
político. Assim, era do interesse político dos reformadores tornar o sistema político brasileiro mais plural e competitivo. De acordo com nosso argumento, o jogo político e as estratégias dos reformadores desenvolvidos no período analisado causou decisivo impacto nas escolhas políticas e institucionais do Governo Provisório, inclusive na ação política de Getúlio em consentir a elaboração de partidos políticos regionais, tanto governistas como de oposição visando às eleições para a Constituinte em 1933. Tal fato fica ainda mais claro quando mergulhamos no contexto de criação desses partidos, ou seja, na radicalização do conflito político da Revolução Paulista de 1932 e na ameaça de um novo conflito armado minando a possibilidade de construir uma agremiação partidária nacional. Restou, como opção mais racional, a escolha de um sistema partidário plural, com a presença de diversos partidos regionais, com relativo espaço de atuação para a oposição, visando a institucionalização do conflito político.

Não obstante, a sustentação dessa nova situação eleitoral partidária, observada ao longo dos três pleitos realizados após a Revolução de 1930, ocorreu graças aos efeitos de instituições eleitorais mais inclusivas e por medidas, como a adoção do voto secreto e a criação da Justiça Eleitoral, presentes no Código Eleitoral de 1932. Em outras palavras, a criação desse novo sistema eleitoral partidário - regional, plural e competitivo - foi fruto tanto de estratégias e ações políticas interessadas de Getúlio e seus aliados como também pelos efeitos positivos das novas instituições eleitorais oriundas do novo Código Eleitoral.

Thiago Silva (nsthiago@ tamu.edu) é Doutorando em Ciência Política pela Texas A\&M University e pela Universidade de São Paulo (USP). Vínculo institucional: Texas A\&M University, College Station, TX, EUA.

Estevão Siva (estevao.silva@usp.br) é Doutorando em Ciência Política pela Universidade de São Paulo (USP). Vínculo institucional: Universidade de São Paulo, São Paulo, SP, Brasil.

\section{Referências}

Antonacci, M.A., 1981. Rio Grande do Sul: as oposições e a Revolução de 1923. Porto Alegre: Mercado Aberto.

Benoit, K., 2001. Institutional Choice in New Democracies: Bargaining over Hungary's 1989 electoral law. Journal of Theoretical Politics, 13(2), pp.153-182. DOI: 10.1177/0951692801013002002.

, 2004. Models of Electoral System Change. Electoral Studies, 94(3), pp.363-389.

, 2007. Electoral Laws as Political Consequences: Explaining the origins and change of electoral institutions. Annual Review of Political Science, 10(1), pp.363-390. DOI: 10.1146/annurev.polisci.10.072805.101608.

Braga, M.S.S., 2013. A agenda dos estudos sobre partidos políticos e sistemas partidários no Brasil. Revista de Discentes de Ciência Política da UFSCAR, 1(1), pp.1-25.

Brasil, A., 1983. Democracia representativa: do voto e do modo de votar. Rio de Janeiro: Leusinger \& Filhos.

Cabral, J.C.R., 1929. Sistema eleitorais do ponto de vista da representação proporcional das minorias. Rio de Janeiro: Francisco Alves.

Cardoso, F.H., 1977. Dos governos militares a Prudente - Campos Sales. In B. Fausto, ed. História geral da civilização brasileira. São Paulo: Difusão Européia do Livro.

Franco, A.A.M., 1965. Evolução da crise brasileira. São Paulo: Companhia Editora Nacional. 1974. História e teoria dos partidos políticos no Brasil. São Paulo: Editora Alfa-Ômega. 1975. Problemas políticos brasileiros. Rio de Janeiro: Editora José Olympio.

Gomes, A.M.C., 1974. Regionalismo e centralização política: partidos e constituinte nos anos 30. São Paulo: Nova Fronteira. ,2009. Jango e a República de 1945-1964: da República Populista à Terceira República. In R. Soihet; M.R.C. Almeida; C. Azevedo; R. Gontijo, eds. Mitos, projetos e praticas politicas: memoria e historiografia. Rio de Janeiro: Civilização Brasileira.

Gomes, S.C., 2006. O impacto das regras de organização do processo legislativo no comportamento dos parlamentares: um estudo de caso da Assembléia Nacional Constituinte. Dados, 49(1), pp.87-118. DOI: 10.1590/S001152582006000100008 .

Hollanda, C.B., 2009. Modos da representação política: o experimento da Primeira República brasileira. Minas Gerais: Editora UFMG.

Kinzo, M.D., 1980. Representação política e sistema eleitoral no Brasil. São Paulo: Editor Símbolo.

Lamounier, B., 2005. Da Independência a Lula: dois séculos de política brasileira. São Paulo: Augurium Editora. 
Lattman-Weltman, F. \& Abreu, A.A., 2008. Dicionário Histórico-Biográfico Brasileiro (DHBB). Rio de Janeiro: CPDOCFGV.

Leal, V.N., 1975. Coronelismo, enxada e voto. São Paulo: Alfa-Ômega.

Lessa, R., 1999. A invenção republicana. Rio de Janeiro: Topbooks.

Limongi, F., 2012. Eleições e Democracia no Brasil: Victor Nunes Leal e a Transição de 1945. Dados, 55, pp.37-69. DOI: 10.1590/S0011-52582012000100002.

Nicolau, J., 2002. História do voto no Brasil. Rio de Janeiro: Jorge Zahar Editor. 2012. Eleições no Brasil: do império aos dias atuais. Rio de Janeiro. Jorge Zahar Editor.

Octávio, J., 1984. A revolução estatizada: um estudo sobre a formação do centralismo em 30. Paraíba: União CIA Editora.

Peixoto, C.V.A., 1995. Getúlio Vargas: diários. Rio de Janeiro: FGV.

Pires, J.M., 2009. A invenção da lista aberta: o processo de implantação da representação proporcional no Brasil. Dissertação de Mestrado. Rio de Janeiro: IUPERJ.

Porto, W.C., 2002. O voto no Brasil. Rio de Janeiro: Topbooks.

Renwick, A., 2010. The Politics of Electoral Reform: Changing the rules of democracy. Cambridge, UK: Cambridge University Press.

Ricci, P. \& Zulini, J., 2012. 'Beheading', Rule Manipulation and Fraud: The approval of election results in Brazil, 1894-1930. Journal of Latin American Studies, 44(03), pp.495-521.

, 2014. Quem ganhou as eleições? A validação dos resultados antes da criação da Justiça Eleitoral. Revista de Sociologia e Política, 21(45), pp.91-105. DOI: 10.1590/S0104-44782013000100008.

Sadek, M.T., 1995. A Justiça Eleitoral e a consolidação da democracia no Brasil. São Paulo: Fundação Konrad-Adenauer.

Santos, R.O., 1937. Código eleitoral anotado. Rio de Janeiro: Editora Metrópole.

Schmitt, R., 2000. Partidos políticos no Brasil (1945-2000). Rio de Janeiro: Jorge Zahar Editor.

Silva, H., 1967. Os tenentes no poder. Rio de Janeiro: Civilização Brasileira. 1968. A crise do Tenentismo. Rio de Janeiro: Civilização Brasileira.

Souza, M.C.C., 1974. O processo político partidário na primeira república. In C.G. Mota, eds. Brasil em perspectiva. São Paulo: Difusão Européia do Livro. 1990. Estado e Partidos Políticos no Brasil (1930 a 1964). São Paulo: Editora Alfa-Ômega.

Telarolli, R., 1982. Eleições e fraudes eleitorais na República Velha. São Paulo: Brasiliense.

Trindade, H., 1979. Aspectos políticos do sistema partidário republicano Rio-Grandense. In J.H. Dacanal \& S. Gonzaga, eds. RS: Economia e Política. Porto Alegre: Editora Vértice.

Viana, O. 1949. Instituições políticas brasileiras: fundamentos sociais do Estado. São Paulo: José Olympio.

Vizentini, P.G.F., 1982. O Rio Grande do Sul e a Política nacional: as oposições civis na crise dos anos 20 e na Revolução de 30. Porto Alegre: Martins Livreiro.

Zulini, J. \& Ricci, P., 2014. The Use of Electoral Manipulation by Political Parties in Oligarchic Regimes: The case of Brazil (1900-1930). In The Australian Political Studies Association Annual Conference. Sydney.

\section{Outras fontes}

Brasil. TSE. 1936. Boletins Eleitorais 1932-1936. Brasília: Tribunal Superior Eleitoral.

\section{Abstract}

In this paper, we aim to understand the process of the Brazilian party and electoral systems' reconfiguration after 1930 and before the first democratic period in the country (1945-1964). Our analysis is focused in two stages: In the relationship between political elites and the formation of a new political and institutional order in the country, and in the effects of institutional changes on the political competition and political representation. Based on new data, we demonstrate that the elections held in 1933 and 1934 were the first plural and competitive elections in Brazil, where the possibility of assuming the office was guaranteed to the opposition. Thus, these elections expose a very different scenario from the one often presented by the consolidated literature on the First Republic of Brazil.

KEYWORDS: Brazilian First Republic; formation of political parties; elections; electoral systems; political representation.

License information: This is an open-access article distributed under the terms of the Creative Commons Attribution License (CC-BY-NC 4.0), which permits unrestricted use, distribution, and reproduction in any medium, provided the original work is properly cited. 
ANEXOA

No que concerne as leis e reformas eleitorais ver a Tabela $1 \mathrm{~A}$

Tabela 1A - Informações sobre as Leis e Reformas Eleitorais Brasileiras (1890-1945)

\begin{tabular}{|c|c|c|c|c|}
\hline Ano & Circunscrição eleitoral & $\begin{array}{l}\text { Número de nomes } \\
\text { possíveis para votação }\end{array}$ & Sistema eleitoral & $\begin{array}{l}\text { Responsáveis pela } \\
\text { apuração dos resultados } \\
\text { eleitorais }\end{array}$ \\
\hline 1890 & Estado & $\begin{array}{l}\text { Tantos nomes quanto } \\
\text { fossem as cadeiras do } \\
\text { Estado na Câmara dos } \\
\text { Deputados }\end{array}$ & $\begin{array}{l}\text { Maioria Simples: os mais } \\
\text { votados nos Estados eram } \\
\text { eleitos }\end{array}$ & $\begin{array}{l}\text { Realizada pela Mesa } \\
\text { Eleitoral }\end{array}$ \\
\hline 1892 & $\begin{array}{l}\text { Distrito de três } \\
\text { Representantes }\end{array}$ & Dois Nomes & $\begin{array}{l}\text { Maioria Simples: Os Três } \\
\text { mais votados do distrito } \\
\text { eram eleitos }\end{array}$ & $\begin{array}{l}\text { Ocorriam duas apurações: } \\
\text { a parcial realizada pela } \\
\text { mesa eleitoral e a fi- } \\
\text { nal, realizada por uma } \\
\text { Junta Apuradora lo- } \\
\text { cal, composta pelos cinco } \\
\text { vereadores mais votados e } \\
\text { cinco cidadãos eleitos pelo } \\
\text { presidente do Governo } \\
\text { Municipal. }\end{array}$ \\
\hline 1904 & $\begin{array}{l}\text { Distrito de Cinco } \\
\text { Representantes }\end{array}$ & $\begin{array}{l}\text { Quatro Nomes e o Eleitor } \\
\text { poderia repetir o voto no } \\
\text { mesmo candidato quatro } \\
\text { vezes (voto cumulativo) }\end{array}$ & $\begin{array}{l}\text { Maioria Simples: os Cinco } \\
\text { Nomes mais votados eram } \\
\text { eleitos }\end{array}$ & $\begin{array}{l}\text { Ocorriam duas apurações: } \\
\text { a parcial realizada pela } \\
\text { mesa eleitoral e a fi- } \\
\text { nal, pelo presidente do } \\
\text { Governo Municipal }\end{array}$ \\
\hline 1916 & $\begin{array}{l}\text { Distrito de Cinco } \\
\text { Representantes }\end{array}$ & $\begin{array}{l}\text { Quatro Nomes e o Eleitor } \\
\text { poderia repetir o voto no } \\
\text { mesmo candidato quatro } \\
\text { vezes (voto cumulativo) }\end{array}$ & $\begin{array}{l}\text { Maioria Simples: os Cinco } \\
\text { Nomes mais votados eram } \\
\text { eleitos }\end{array}$ & $\begin{array}{l}\text { Ocorriam duas apurações: } \\
\text { a parcial realizada pela } \\
\text { mesa eleitoral. E a final era } \\
\text { realizada na capital do } \\
\text { Estado por uma junta } \\
\text { apuradora composta por } \\
\text { membros do poder } \\
\text { judiciário }\end{array}$ \\
\hline 1932 & Estado & $\begin{array}{l}\text { Em tantos nomes quanto } \\
\text { fossem as cadeiras do } \\
\text { estado na Câmara dos } \\
\text { Deputados }\end{array}$ & $\begin{array}{l}\text { Sistema misto: parte } \\
\text { proporcional, parte } \\
\text { majoritário }\end{array}$ & Justiça Eleitoral \\
\hline 1945 & Estado & $\mathrm{Um}$ & $\begin{array}{l}\text { Sistema proporcional: as } \\
\text { cadeiras não alocadas pelo } \\
\text { quociente eleitoral eram } \\
\text { alocadas para o maior } \\
\text { partido }\end{array}$ & Justiça Eleitoral \\
\hline
\end{tabular}

Fonte: Os autores, a partir de Nicolau (2002, p.33, p.51; 2012).

\section{ANEXO B - Notas Metodológicas}

Nota Metodológica 1

Os dados contidos em todas as tabelas e gráficos deste estudo foram retirados dos boletins eleitorais de 1933, 1934 e 1935 (TSE do Brasil 1936), através da consulta direta em visitas diárias ao Instituto de Estudos Brasileiros (IEB). Os arquivos digitalizados dos boletins eleitorais estão disponíveis no 
seguinte endereço: http://people.tamu.edu/ nsthiago/research.html. Acesso em: 11 nov. 2015.

A elaboração das tabelas foi fruto da construção de um banco de dados pelos autores. A classificação dos partidos em oposição e governo, em todas as tabelas deste estudo, foi feita com base na consulta do Dicionário HistóricoBiográfico da Fundação Getúlio Vargas (FGV), obedecendo os seguintes critérios: Governo: todos os partidos criados pelos interventores de estado, ou que, mesmo sendo criados por outro ator político, apresentassem apoio ao Governo Provisório; Oposição: os partidos criados pelas antigas oligarquias, que visavam recuperar o poder perdido ou, até mesmo, alguns grupos políticos que apoiaram Vargas na Revolução de 30, os quais, porém, vendo o Tenentismo ganhar muito espaço no governo provisório se tornaram posteriormente oposição ao Governo Vargas, tais como os Republicanos Liberais, Partido Democrático de São Paulo e Partido Liberal do Rio Grande do Sul. Os autores se valeram ainda dos diários de Getúlio Vargas (Peixoto 1995).

Nota metodológica 2

A classificação dos grupos políticos apresentados nas Tabelas 1 e 2 foi baseada no trabalho de Silva (1967). Seguimos a tipologia desse autor ao classificar os grupos como: oligarquia dissidente; republicano liberal, e tenentistas. A partir dessa tipologia, por meio de consulta ao Dicionário Histórico-Biográfico da FGV, definimos os grupos do modo em que se segue:

1) Oligarcas dissidentes: Políticos pertencentes aos antigos quadros dos Partidos Republicanos, mas que passaram a se opor à hegemonia da oligarquia paulista; especialmente depois que o Presidente Washington Luís, paulista, indicou para sua sucessão Júlio Prestes, também do estado de São Paulo.

2) Republicano Liberal: Históricos opositores aos grupos políticos dominantes na Primeira República, como o Partido Democrático, em São Paulo e o Partido Liberal, no Rio Grande do Sul. Estão entre esses opositores Assis Brasil, Rui Barbosa, Nilo Peçanha e outros, que acusavam o modus operandi da Primeira República de ser baseado na fraude e na violência contra o eleitor, ferindo os valores liberais.

3) Tenentistas: Grupo existente no Exército, ideologicamente contrários às instituições liberais, principalmente, aos partidos políticos.

No que diz respeito à classificação referente aos civis ligados à Revolução de 1930, foram assim classificados aqueles indivíduos que apoiaram a Revolução, mas que não pertenciam a nenhum grupo político na Primeira República (Vizentini 1982).

Nota metodológica 3

A Tabela 1B apresenta detalhadamente a classificação dos políticos, de acordo com os critérios descritos na nota metodológica 2.

Nota metodológica 4

A Tabela 2B apresenta, detalhadamente, os partidos políticos estaduais presentes no contexto político posterior à Revolução de 1930, bem como seus objetivos e como se compunham os respectivos quadros partidários. As informações referentes à numeração do "quadro partidário" estão descritas na legenda abaixo da tabela apresentada. As informações aqui contidas foram elaboradas pelos autores com base nas consultas ao Dicionário HistóricoBiográfico da FGV. 
Tabela 1B - Categorias e Critérios para a Classificação dos Atores Políticos

\begin{tabular}{ll}
\hline Categoria & Critério \\
\hline Não apresentou carreira política na Primeira República & O indivíduo não praticou nenhuma atividade nos momentos \\
políticos anteriores à instalação do Governo Provisório. \\
Ocupou cargos secundários na Primeira República & O indivíduo ocupou cargos políticos não relevantes na Primeira \\
República, tais como Vereador e Delegado. \\
Tenentista & O indivíduo era ligado ao Movimento Tenentista. \\
Opositor na Primeira República & O indivíduo era de partido(s) de oposição, ou participou de algum \\
movimento oposicionista à Primeira República.
\end{tabular}

Fonte: Os autores, com base no Dicionário-Histórico Biográfico Brasileiro (2008).

Tabela 2B - Partidos Políticos Presentes no Contexto Político Pós Revolução de 30

\begin{tabular}{|c|c|c|c|}
\hline $\mathbf{U F}$ & Partido & Objetivo & Quadro partidário \\
\hline $\mathrm{AC}$ & Lista Chapa Popular/Partido Popular & $\begin{array}{l}\text { Chapa criada para fazer oposição ao Governo } \\
\text { Provisório no Estado }\end{array}$ & 1 \\
\hline $\mathrm{AC}$ & Legenda Autonomista do Acre & $\begin{array}{l}\text { Legenda de sustentação política ao Governo } \\
\text { Provisório no Estado }\end{array}$ & 2 \\
\hline $\mathrm{AL}$ & Partido Nacional Socialista & $\begin{array}{l}\text { Partido de sustentação política ao Governo } \\
\text { Provisório no Estado }\end{array}$ & 3 \\
\hline $\mathrm{AL}$ & Partido Republicano de Alagoas & $\begin{array}{l}\text { Partido reorganizado para fazer oposição ao } \\
\text { Governo Provisório }\end{array}$ & 1 \\
\hline $\mathrm{AM}$ & Partido Popular do Amazonas & Partido criado visando às eleições de 1934 & 4 \\
\hline $\mathrm{AM}$ & União Cívica Amazonense & $\begin{array}{l}\text { Aliança de sustentação política ao Governo } \\
\text { Provisório no Estado }\end{array}$ & 4 \\
\hline $\mathrm{AM}$ & Aliança Trabalhista Liberal & $\begin{array}{l}\text { União do Partido Trabalhista, Liberal e } \\
\text { Republicano do Amazonas }\end{array}$ & 2 \\
\hline $\mathrm{AM}$ & Partido Socialista do Amazonas & $\begin{array}{l}\text { Partido criado para disputar as eleições para a } \\
\text { constituinte }\end{array}$ & \\
\hline $\mathrm{BA}$ & Lista a Bahia ainda é a Bahia & $\begin{array}{l}\text { Chapa criada para fazer oposição ao Governo } \\
\text { Provisório no Estado }\end{array}$ & 1 \\
\hline $\mathrm{BA}$ & Partido Social Democrático da Bahia & $\begin{array}{l}\text { Partido de sustentação política ao Governo } \\
\text { Provisório no Estado }\end{array}$ & 3 \\
\hline $\mathrm{BA}$ & Legenda Octávio Mangabeira & $\begin{array}{l}\text { Legenda criada para fazer oposição ao Governo } \\
\text { Provisório em } 1934\end{array}$ & 1 \\
\hline $\mathrm{CE}$ & Partido Social Democrático do Ceará & $\begin{array}{l}\text { Partido de sustentação política ao Governo } \\
\text { Provisório no Estado }\end{array}$ & 3 \\
\hline $\mathrm{CE}$ & Liga Eleitoral Católica & $\begin{array}{l}\text { Legenda ligada a igreja católica e no Ceara fez } \\
\text { oposição ao Governo Provisório }\end{array}$ & 1 \\
\hline
\end{tabular}


DF Partido Economista Democrático do Brasil

DF Legenda Frente Única

DF Partido Autonomista do Distrito Federal

ES

ES

Partido Social Democrático do Espirito Santo

ES Partido da Lavoura

GO Coligação Libertadora

GO Partido Social Republicano de Goiás

MA União Republicana Maranhense

MA Oposições coligadas

MA Partido Social Democrático do Maranhão

MA Partido Republicano do Maranhão

MG Partido Republicano Mineiro

MG Partido Progressista

MT Partido Constitucionalista

MT Partido Evolucionista do MT

MT Partido Liberal Mato Grossense

PA Partido Liberal do Pará

PA Frente Única Paraense

PB Partido Progressista da Paraíba

PB Partido Republicano Libertador da Paraíba

PE Partido Republicano Social

PE Partido Social Democrático de Pernambuco

PI Lista Hugo Napoleão

PI Coligação Piauiense

PI Partido Nacional Socialista

PI Partido Progressista do Piaui
Criado por comerciantes e industriais do Rio de Janeiro para fazer oposição ao GP

Coligação de todos os partidos do DF para fazer oposição ao Partido Autonomista

Partido de sustentação política ao Governo

Provisório no estado

Partido criado para fazer oposição ao Governo

Provisório

Partido de sustentação política ao Governo

Provisório no Estado

Partido criado para fazer oposição ao Governo

Provisório no Estado

Coligação de oposição ao interventor e o governo federal

Partido de sustentação política ao Governo Provisório no Estado

Legenda criada para fazer oposição ao Governo Provisório no Estado

Coligação formada pelo PRM e a URM para

fazer oposição ao PSD nas eleições de 1934

Partido de sustentação política ao Governo Provisório no Estado

Partido criado para fazer oposição ao Governo Provisório no Estado

Partido reorganizado para fazer oposição ao Governo Provisório no Estado

Partido de sustentação política ao Governo Provisório no Estado

Criado para fazer oposição ao Governo Provisório nas eleições para a constituinte

Partido criado ara fazer oposição ao Governo Provisório nas eleições de 1934

Partido de sustentação política ao Governo Provisório no Estado

Partido de sustentação política ao Governo Provisório no Estado

Aliança de oposição ao Governo Provisório no 1 Estado

Partido de sustentação ao Governo Provisório no Estado

Partido criado para fazer oposição ao governo Provisório

Partido criado para fazer oposição ao Governo Provisório

Partido de sustentação política ao Governo

Provisório no Estado

Chapa criada para disputar as eleições de 1933

Coligação criada para fazer oposição ao Governo Provisório no Estado

Partido de sustentação política ao Governo

Provisório no Estado

Partido criado em 1934 em substituição ao

Partido Nacional Socialista 
PR Partido Republicano do Paraná

PR Partido Liberal Paranaense

PR Partido Social Democrático do Paraná

PR Partido Social Nacionalista

RJ Partido Republicano Fluminense

RJ Partido Popular Radical

RJ União Progressista Fluminense

RJ Partido Evolucionista do RJ

RJ Partido Socialista Fluminense

RN Partido Social Nacionalista

RN Aliança Social do RN

RN Partido Social Democrático do Rio Grande do Norte

RN Partido Popular do Rio Grande do Norte

RS Chapa Única

RS Partido Republicano Liberal

SC Partido Liberal Catarinense

SC Reação Republicana

SC Coligação por SC

SE União Republicana de Sergipe

SE Lista Liberdade e Civismo/ Partido Republicano de Sergipe

SE Partido Social Democrático de Sergipe

SP Partido da Lavoura

SP Partido Socialista Brasileiro

SP Partido Constitucionalista

SP Partido Republicano Paulista

SP Legenda Chapa Única
Partido criado para fazer oposição ao Governo Provisório

Partido criado para fazer oposição ao Governo Provisório no Estado

Partido de sustentação política ao Governo Provisório no Estado

Partido criado para fazer oposição ao Governo Provisório

Partido criado para fazer oposição ao Governo Provisório

Partido de apoio ao Governo Provisório no Estado

Partido criado para fazer oposição ao Governo Provisório no Estado

Fundado por dissidentes do PRF visava fazer oposição ao Governo Provisório

Criado com o propósito de se tornar uma opção socialista no estado

Partido de apoio ao Governo Provisório no Estado

Coligação criada entre PSD e o PSN visando combater o PPR nas eleições de 1934

Partido de sustentação política ao Governo Provisório no Estado

Partido criado para fazer oposição ao Governo Provisório no Estado

Chapa de oposição ao Governo Provisório no Estado

Partido de sustentação política ao Governo Provisório no Estado

Partido de sustentação política ao Governo Provisório

Coligação de sustentação política ao Governo Provisório

Criada para fazer oposição ao Governo Provisório

Criado por Três políticos visando as eleições para a constituinte

Aliança de apoio ao Governo Provisório no Estado na constituinte

Partido de sustentação política ao Governo Provisório no Estado nas eleições de 1934

Partido de sustentação política ao Governo Provisório no Estado

Partido de sustentação política ao Governo Provisório no Estado

Partido organizado por Armando Salles a fim de solucionar a crise política paulista

Reorganizado em 1934 visava fazer oposição a Armando Salles e a Vargas

Legenda criada para fazer oposição ao Governo Provisório no Estado em 1933
1

Fonte: Os autores, com base no Dicionário-Histórico Biográfico Brasileiro (2008). 
Legenda da categoria "quadro partidário" presente na Tabela 2B:

$1=$ Membros da antiga oligarquia

$2=$ Tenentistas

$3=$ Tenentistas + Oligarcas Dissidentes

4 = Tenentistas + Opositores da Primeira República, mas sem grande visibilidade política

5 = Tenentistas + civis ligados à Revolução de 1930

6 = Oligarcas Dissidentes + opositores a Primeira República, mas sem grande visibilidade política

$7=$ Tenentistas + oligarcas Dissidentes e Liberais

$8=$ Tenentistas, opositores políticos sem grande visibilidade política e civis ligados à Revolução de 1930

9 = Opositores políticos sem grande prestigio político e civis ligados à Revolução de 1930

$10=$ Opositores políticos sem grande visibilidade política, e liberais

11 = Civis ligados a Revolução de 1930

$12=$ Antigos oligarcas e liberais

13 = Oligarcas Dissidentes

$14=$ Socialistas

$15=$ Sindicalistas

16 = Empresários 


\section{ERRATA}

No artigo Eleições no Brasil antes da democracia: o Código Eleitoral de 1932 e os pleitos de 1933 e 1934, DOI 10.1590/1678-987315235604, publicado na Revista de Sociologia e Política Vol. 23 N. 56, p. 75-106, constatou-se o seguinte erro:

\section{Página 94}

No título do Gráfico 4, onde se lê

1943

Leia-se

1934 